\title{
Advection, diffusion and mortality of Pacific herring larvae Clupea harengus pallasi in Bamfield Inlet, British Columbia
}

\author{
Michael D. McGurk \\ Envirocon Pacific Ltd, 205-2250 Boundary Road, Burnaby, British Columbia, Canada V5M 3Z3
}

\begin{abstract}
Advection, diffusion, total mortality and starvation mortality were measured for 2 cohorts of Pacific herring larvae Clupea harengus pallasi in Bamfield Inlet, British Columbia, in order to determine the roles of offshore dispersal, population density and starvation in the dynamics of populations. The most striking differences between the 2 cohorts were in initial density, total mortality, and diffusion: the initial density of the cohort that hatched in 1981 (Cohort 2) was 78 times lower than the density of the cohort that hatched in 1982 (Cohort 6); total mortality was 8 times lower in Cohort 2 , $0.02 \mathrm{~d}^{-1}$, than in Cohort $6,0.16 \mathrm{~d}^{-1}$; and Fickian diffusion was 3 to 6 times lower in Cohort $2,0.08 \mathrm{~km}^{2}$ $\mathrm{d}^{-1}$, than in Cohort $6,0.31$ to $0.48 \mathrm{~km}^{2} \mathrm{~d}^{-1}$ Starving larvae, identified with a morphometric index, were found in the 1 to $26 \mathrm{~d}$ age group of both cohorts and starvation mortality followed the same trajectory in both cohorts: an increase in magnitude from $0 \mathrm{~d}^{-1}$ at hatch to a maximum of $1.0 \mathrm{~d}^{-1}$ at ages 5 to $7 \mathrm{~d}$ and then a decline to $0 \mathrm{~d}^{-1}$ at age $20 \mathrm{~d}$. That the average magnitude of starvation mortality did not vary with total mortality, as did initial density and the rates of diffusion, suggests that starvation was only one of several agents of mortality and that density-dependent predation and offshore dispersal were equally important factors.
\end{abstract}

\section{INTRODUCTION}

Year-class strength of fish populations is widely believed to be controlled in large part by the survival of their early life history stages (Rothschild 1986). Consequently, the causes of mortality of fish eggs and larvae form an important area of fisheries research. The primary objective of the work summarized in this paper was to measure rates of dispersal (advective and diffusive), total mortaliy, and starvation mortality for cohorts of wild Pacific herring larvae Clupea harengus pallasi in Bamfield Inlet, British Columbia. The secondary objective was to use these data to assess the relative importance of offshore dispersal, cohort density and starvation mortality to total mortality. This paper reports that total mortality is highly variable between cohorts and that this variability is not due to variation in the rates of starvation mortality, but that it may be more closely linked to offshore dispersion of the larvae and to the initial density of a cohort. This report is the third and final part of a study on the ecology of Pacific herring larvae in Bamfield Inlet. Earlier papers have reported data on age and growth (McGurk 1987a) and spatial patchiness (McGurk 1987b).

\section{Advection-diffusion-mortality models}

This section describes the population models used to estimate dispersal and total mortality. Accurate measurement of total mortality depends on how well the method of measurement accounts for the potential bias introduced by dispersal of larvae into or out of the sampling area. Catch curve analysis (Smith \& Richardson 1977) was not used to estimate mortality in cohorts of Bamfield Inlet herring larvae because the primary assumption of the method was violated: herring larvae were observed to move out of Bamfield Inlet and into Trevor Channel within $2 \mathrm{wk}$ of mean hatch dates and it was not possible for logistical reasons to sample over an area large enough to encompass the entire population. Futhermore, estimates of dispersal were desired in order to test the offshore dispersal hypothesis.

Dispersal has 2 components: advection of the centroid of a patch of larvae away from its hatch site, and diffusion of fish away from the centroid. Only recently have attempts been made to measure both components for populations of fish eggs and larvae (Talbot 1977 , Koslow et al. 1985, Munk et al. 1986, Heath \& MacLachlan 1987). All of the methods used by these 
authors are ultimately based on 2-dimensional advection-diffusion models that have been used previously to describe the movements of conservative substances such as salt or dye in rivers (Diachishin 1963, Cleary \& Adrian 1973) and in the open sea (Talbot \& Talbot 1974, Okubo 1980)

$\frac{\delta N}{\delta t}=-u \frac{\delta N}{\delta x}-v \frac{\partial N}{\delta y}-\frac{\delta}{\delta x}\left(K_{x} \frac{\delta N}{\delta x}\right)-\frac{\delta}{\delta y}\left(K_{y} \frac{\delta N}{\delta y}\right)$

where $N=\operatorname{density}\left(10^{-3} \mathrm{~m}^{-3}\right)$ at distances $x(\mathrm{~km})$ and $y$ $(\mathrm{km})$ from the hatch site at age $t(\mathrm{~d}): u=$ rate of advection along the $\mathrm{x}$-axis $\left(\mathrm{km} \mathrm{d}^{-1}\right) ; v=$ rate of advection along the $y$-axis $\left(\mathrm{km} \mathrm{d}^{-1}\right)_{i} K_{x}=$ coefficient of Fickian diffusion in the $\mathrm{x}$-axis $\left(\mathrm{km}^{2} \mathrm{~d}^{-1}\right)$; and $K_{y}=$ coefficient of Fickian diffusion in the y-axis $\left(\mathrm{km}^{2} \mathrm{~d}^{-1}\right)$. Eq. (1) states that the rate of change of larval density with time is equal to the flux of density in the $x$ and $y$ axes by means of turbulent diffusion, minus the density lost through advection. The third spatial dimension, depth, was not included in this model because there was no data available on the depth distribution of Bamfield Inlet herring larvae.

Eq. (1) was solved by making the following simplifying assumptions:

(1) $K_{x}$ and $K_{y}$ are constant with $x$ and $y$, respectively. This is Fickian diffusion in which the diffusive flux is proportional to the gradient of density. It is the simplest of the 3 major types of diffusion and the only type that has been used to describe diffusion in fish eggs and larvae (Talbot 1977, Fortier \& Leggett 1982, Koslow et al. 1985, Munk et al. 1986, Heath \& MacLachlan 1987). Dye-release experiments in the sea tend to support either Joseph-Sendner diffusion, in which horizontal variance increases directly with the scale of diffusion, or Ozmidov diffusion, in which horizontal variance increases with the scale of diffusion to the $4 / 3$ power (Talbot 1977, Okubo 1980). However, the latter 2 types of diffusion are even less applicable to herring larvae than Fickian diffusion because, as will be shown, the diffusion coefficients of Pacific herring larvae probably decrease with increasing age of the fish as the mid-and late-stage larvae cease dispersal and begin to coalesce in schools.

(2) Hatching is instantaneous at $t=0$. This is judged to be a reasonable assumption because masses of Pacific herring eggs deposited during the same spawning event take only 2 to $4 \mathrm{~d}$ to completely hatch (Hourston et al. 1984, McGurk 1986).

(3) Larvae are retained in a layer of constant depth $H(\mathrm{~km})$ and they are distributed evenly within this layer (vertical isotrophy). This assumption was necessary in order to obtain a solution to Eq. (1) and because there was little information on the distribution of larval herring with depth. It was implicitly made by Munk et al. (1986) and Heath \& MacLachlan (1987) when they used depth-averaged concentrations of herring larvae in order to calculate coefficients of diffusion.

The solution is

$$
\begin{gathered}
N(y, x, t)= \\
\frac{C}{4 \pi H \sqrt{K_{x} K_{y}} t} \exp \left[-\frac{\left(y-y_{0}-v t\right)^{2}}{4 K_{y} t}-\frac{\left(x-x_{0}-u t\right)^{2}}{4 K_{x} t}\right]
\end{gathered}
$$

where $N(y, x, t)=$ density of larvae at coordinates $y$ and $x$ and age $t_{i} C=$ number of larvae hatched per unit volume of upper Bamfield Inlet; $y_{0}=\operatorname{distance}(\mathrm{km})$ on the $y$-axis between the origin of the coordinate system and the hatch site, and $x_{0}=$ distance $(\mathrm{km})$ on the $\mathrm{x}$-axis between the origin and the hatch site.

Talbot (1977), Koslow et al. (1985), Munk et al. (1986) and Heath \& MacLachlan (1987) did not include a term for total natural mortality, $Z$, in their models of diffusion of fish eggs and larvae. In doing so they were implicitly assuming that the 2 processes are independent of each other, an assumption which may not hold for all populations of fish eggs and larvae under all oceanographic conditions. Ideally, it is preferable to estimate advection, diffusion and mortality parameters simultaneously. Therefore, for this study Eq. (1) was modified by adding $-Z N$ to the right-hand side. It was solved following an example for the 1-dimensional diffusion of a population given by Okubo [1980: Eq. (6.25)] by assuming that $Z$ was constant with age over the larval stage. This assumption was made in all previous studies of natural mortality in Pacific herring larvae (Stevenson 1962, Iizuka 1966) and Atlantic herring larvae Clupea harengus harengus (Das 1968, Dragesund \& Nakken 1971, 1973, Graham \& Chenoweth 1973, Lough et al. 1981, Henderson et al. 1984, Munk et al. 1986, Heath \& MacLachlan 1987) and it will be shown to be an appropriate assumption for Bamfield inlet herring larvae in this report. The solution is

$$
\begin{gathered}
N(y, x, t)= \\
\frac{C}{4 \pi H \sqrt{K_{x} K_{y}} t} \exp \left[-\frac{\left(y-y_{0}-v t\right)^{2}}{4 K_{y} t}-\frac{\left(x-x_{0}-u t\right)^{2}}{4 K_{x} t}-Z t\right]
\end{gathered}
$$

Note that when Eq. (3) is rearranged as

$$
\begin{array}{r}
\ln \left[N(y, x, t) 4 \pi H \sqrt{K_{x} K_{y}} t\right]+\frac{\left(y-y_{0}-v t\right)^{2}}{4 K_{y} t}+\frac{\left(x-x_{0}-u t\right)^{2}}{4 K_{x} t} \\
=\ln C-Z t
\end{array}
$$

it takes a form similar to the regression equation used by Heath \& MacLachlan (1987) to estimate $Z$, with the exception that they did not include the advection parameters $y_{0}, v_{1} x_{0}$ and $u$ in their dispersion model. 
A major assumption of the models discussed above is that larvae are distributed normally along the horizontal axes. This assumption is obviously violated in the Bamfield Inlet-Trevor Channel case because the larvae are not free to move in all horizontal directions (Fig. 1), but the assumption is unavoidable because the alternative is to employ a 1-dimensional, river-type model instead of a 2 -dimensional model. This would be even less realistic because movement of larvae along 1 of the 2 axes would be ignored. Furthermore, the assumption of radial or elliptical symmetry is violated to some degree in every natural situation. Even in open seas, the distribution of fish eggs and larvae is never symmetrical along 2 horizontal axes and is rarely symmetrical along 1 axis because fronts, tidal currents, eddies and other phenomena distort the distribution (Talbot 1977, Koslow et al. 1985, Munk et al. 1986 , Heath \& MacLachlan 1987). The degree of bias introduced to the estimates of advection, diffusion and mortality by the application of a 2-dimensional model is ameliorated by the fact that the equation of motion for a population dispersing from a reflecting boundary (such as the head of Bamfield Inlet and the eastern shore of Trevor Channel) is identical to the equation for a population dispersing in an environment with no boundaries, except that the density at hatch [parameter $C$ in Eqs. (2) and (3)] is doubled (Okubo 1980).

Not all of the 9 parameters of Eq. (3) may contribute significantly to the fit of the model to data, but compo- nents of Eq. (1) can be removed to give simpler versions of Eq. (3). There are 9 models, including Eq. (3), that incorporate $Z$. In this study, the best fit to the 4 data sets was obtained by searching among these 9 models.

\section{METHODS}

Study site. Bamfield Inlet $\left(48^{\circ} 50^{\prime} \mathrm{N}, 125^{\circ} 08^{\prime} \mathrm{W}\right)$ is a $3.8 \mathrm{~km}$ long inlet on the southern coast of Barkley Sound, Vancouver Island, British Columbia, Canada (Fig. 1). It has a surface area of $1.23 \mathrm{~km}^{2}$ and is separated into 2 basins by Burlo Island, the largest of 3 islands in the middle of the Inlet. The upper basin, southwest of Burlo Island, is $2.0 \mathrm{~km}$ long with an average width of $354 \mathrm{~m}$. Depth at Mean Water Level (MWL) increases from $1 \mathrm{~m}$ at the head of the Inlet to $11 \mathrm{~m}$ at the northern tip of Burlo Island. The lower basin is $1.8 \mathrm{~km}$ long with an average width of $294 \mathrm{~m}$. Depth at MWL increases continuously from $11 \mathrm{~m}$ at the northern tip of Burlo Island to $47 \mathrm{~m}$ at the mouth of the Inlet. The largest stream entering the Inlet is a small intermittent creek at the Inlet's head.

Bamfield Inlet is a partially mixed estuary. Surface water temperatures in the spring and summer range from 8 to $17^{\circ} \mathrm{C}$. A thermocline occurs at 4 to $6 \mathrm{~m}$ in the summer, below which the water ranges from 8 to $10^{\circ} \mathrm{C}$. Surface salinity at the mouth of the Inlet ranges from 22 to $31 \%$ (L. Druehl, Simon Fraser University, Burnaby,

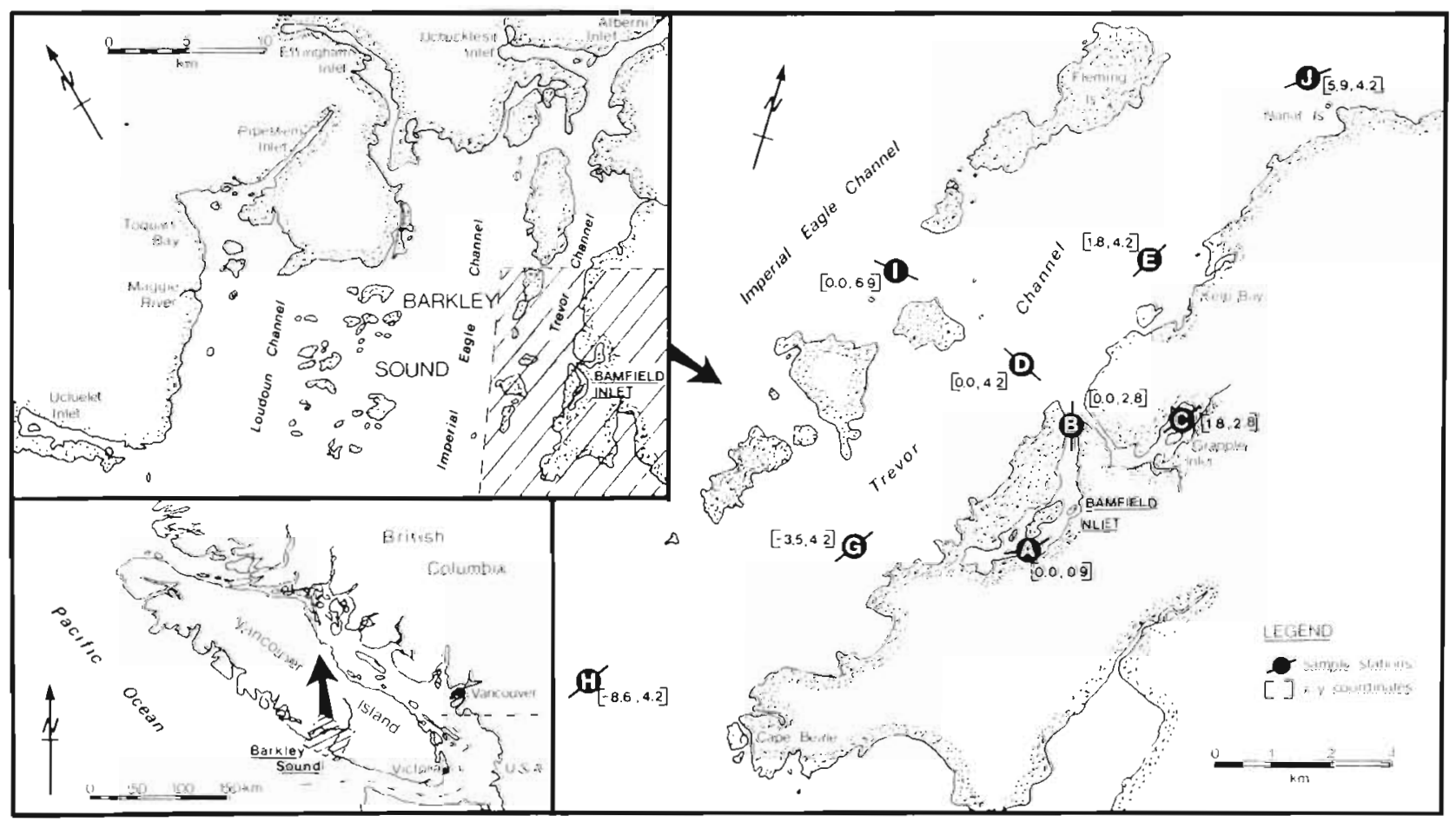

Fig. 1. Barkley Sound showing the Bamfield Inlet-Trevor Channel area sampled in this study. Plankton sampling stations are identified by letters $\mathrm{A}$ to $\mathrm{J}$ and by $x-y$ coordinates 
B.C., unpubl.). There is shallow halocline in the top $4 \mathrm{~m}$, and below $10 \mathrm{~m}$ the water is a constant 31 to $32 \%$. The seaward flow of the low-salinity surface layer is balanced by a return flow of high-salinity ( $31 \%$ ) oceanic water into the Inlet below the halocline. The rate of flushing of the Inlet due to this exchange process is determined almost entirely by the amount of rainfall captured by the watershed of Bamfield Inlet.

Rainfall and wind speed data used in this study were provided by the Canadian Department of the Environment. Rainfall was measured twice daily at a climatological station in Grappler Inlet ('Bamfield East', Stn $1030605 ; 48^{\circ} 58^{\prime} \mathrm{N}, 125^{\circ} 07^{\prime} \mathrm{W}$ ), using a tipping bucket. Wind speed was measured at a climatological station at the Cape Beale Lighthouse (Stn 1031316; $48^{\circ} 47^{\prime} \mathrm{N}, 125^{\circ} 13^{\prime} \mathrm{W}$ ) every $3 \mathrm{~h}$ beginning at $01: 00 \mathrm{~h}$, using an anemometer mounted on a 3 m mast atop the $16.2 \mathrm{~m}$ high lighthouse. Tides in the Bamfield area are of the semi-diurnal type. The height of the water at flood and ebb was taken from tide tables prepared for Bamfield Inlet (Bamfield Marine Station, Bamfield, B.C., unpubl.).

Herring spawning. For purposes of stock management, the Bamfield Inlet herring spawning ground is defined by the Canadian Department of Fisheries and Oceans, in ascending order of scale, as Locality 1122 of Management Section 235, Unit 28 and Division 6 (Hourston \& Hamer 1979). Herring spawn in the Inlet almost every year between February and April. Spawning usually occurs on the seagrass of the intertidal zone at or near the head of the Inlet (southeast of plankton sampling $\mathrm{Stn}$ A), but small sub-tidal spawnings have also been observed on the shores of Burlo Island. Although Bamfield Inlet is the site most often favored by herring spawning on the southeastern coast of Barkley Sound, small spawnings have been reported since 1971 at other locations including Grappler Inlet, Kelp (Roquefeuil) Bay, Fleming Island and Nanat Islet (Hourston \& Hamer 1979, Haegele \& Fitzpatrick 1983).

Sampling. Plankton samples were taken from March to May in 1981 and 1982 using 2 types of gear: twin bongo plankton-nets and a night-light. Plankton-net catches of herring larvae were used to assess net evasion, to calculate rates of mortality, advection and diffusion and to assess condition of the larvae. Night-light catches were used only to assess net evasion.

Two plankton-net stations were sampled in the Inlet: upper Bamfield (A) and off the Bamfield Marine Station (B). Plankton-net samples were also taken at a station in Grappler Inlet (C), and at 6 stations in Trevor Channel, off Bamfield Inlet (D), Kelp Bay (E), Whittlestone Point (G), offshore of Cape Beale (H), Ohiat Rock (I) and Nanat Islet (J). The plankton-nets were $1.5 \mathrm{~m}$ long with a mouth diameter of $40 \mathrm{~cm}$ and a mesh diameter of $471 \mu \mathrm{m}$. They were towed at 1 to $2 \mathrm{~m} \mathrm{~s}^{-1}$ at a depth of about $2 \mathrm{~m}$ in Bamfield Inlet and at some stations outside the Inlet. In 1982 some of the tows outside the Inlet were oblique tows to between 20 and $50 \mathrm{~m}$ depth. The entire water columns at Stns A and C were sampled, but only the upper 2 to $50 \mathrm{~m}$ of the water column were sampled at the other 7 stations. Each tow took 5 to 15 min to complete after which the contents were preserved in $2 \%$ formaldehyde and $30 \%$ seawater.

Each herring larva was counted in plankton-net samples with less than $10^{4}$ herring larvae. Samples with more were subdivided with a plankton-splitter and at least 3 subsamples were counted. The mean number of larvae per subsample was multiplied by the number of subsamples to obtain the estimated total number. The volume of water filtered by the nets was obtained by a flowmeter placed slightly off center in the mouth of one of the nets. Herring larval density was expressed as the number of fish per $10^{3} \mathrm{~m}^{3}$ of water filtered in order to avoid using fractional numbers of larvae per $\mathrm{m}^{3}$.

The night-light floated at the sea surface at the dock of the Bamfield Marine Station, opposite Stn D. It was set out after twilight and plankters were allowed to accumulate about it for several hours. A dipnet was used to capture any fish within $0.5 \mathrm{~m}$ of the light. Larvae were immediately preserved in $2 \%$ formaldehyde and $30 \%$ seawater.

Age. Age of herring larvae, $t$, was the number of days between the date of sampling and the date of $50 \%$ hatch of a cohort. Date of $50 \%$ hatch was back-calculated from the rate of decline with time of the percent of yolk sac larvae in the catches. These calculations are shown in McGurk (1987a).

Advection, diffusion and total mortality. The advection-diffusion-mortality models were based on an $x-y$ coordinate system which had its origin $(x=0, y=0)$ at the head of Bamfield Inlet where the largest egg beds (those of Cohort 6) were observed (Fig. 1). The x-axis was parallel to the southern coast of Trevor Channel and the $y$-axis was at right angles to it. Bamfield Inlet was treated as a pipe at right angles to the southern coast of Trevor Channel with a constant $x$ value. Thus, sampling Stns $A, B, D$ and I had the same $x$ coordinate.

The models described by Eq. (3) and its variants were transformed with natural logarithms because the transformed models provided more cases of convergence with lower residual sums of squares. The In-transformed models were fit to the data with program NL2SNO (Moore 1984, 1986), which is based on an adaptive non-linear least-squares algorithm written by Dennis et al. (1981a, b) and modified by Gay (1983). The algorithm calculates parameter values of a nonlinear function by minimizing the sum of the squared differences between the data and the function. It will 
not converge to the optimum solution unless all the parameters in the function contribute to the fit of the function to the data. If one or more of the parameters does not contribute to the fit, which means it is linearly dependent on another parameter, then the algorithm reaches a false convergence and stops without calculating a variance-covariance matrix. Thus, model building was a 2-step process: the first step was to fit all 9 possible versions of Eq. (3) to the data and then reject those versions that did not converge because they contained too many parameters. Models were not rejected until it was confirmed by repeated runs of the program with different initial parameter values that the false convergence was due solely to an over-specified model and not to initializing the parameters too far from the optimum. The set of remaining models was also subjected to repeated runs with varying initial parameter values in order to verify that they were the global solutions for that model and that data set and not just local optima. The second step was to reject those models in that set that had unrealistic parameter values, primarily those with negative $Z$. The most appropriate model was the one from the set of remaining models that explained the greatest amount of variance in the data. Explained variance was measured using the adjusted coefficient of determination, $R_{a}^{2}$ (Kvâlseth 1985)

$$
\begin{aligned}
& R_{a}^{2}=1-\frac{n\left(1-R^{2}\right)}{n-\frac{i}{i}} \\
& R^{2}=1-\frac{\sum^{n}(g-\hat{g})^{2}}{\sum^{n}(g-\bar{g})^{2}}
\end{aligned}
$$

where $g=$ the dependent variable (density of herring larvae); $\hat{g}=$ the estimated value of $g$ from the nonlinear model; $\bar{g}=$ the arithmetic mean of $g ; n=$ the number of observations; and $i=$ the number of model parameters. An adjusted coefficient of determination was necessary in order to take into account the fact that some fraction of the increment in explained variance achieved by increasing the number of parameters was due solely to the increased number of parameters. The end result of this process was the selection of a model that had a minimum number of parameters, realistic parameter values with relatively small variances and, within these constraints, explained the greatest amount of variance in the data set. There is 1 and only 1 model from the set of 9 possible models that can meet these criteria for each data set. There are no other combinations of $Z, K_{x}$ $K_{y}, C, y_{0}, V, x_{0}$ or $u$, and no other combinations of parameter values that provides as good a fit or a better fit than the model chosen after this selection process.

The statistical significance of a model was estimated from the critical values for correlation coefficients, $r$, given by Rohlf \& Sokal (1969: Table Y). These critical values are appropriate for this purpose because $R_{a}$ is always equal to or less than $r$.

Sample analysis. Herring larvae were stored at $20^{\circ} \mathrm{C}$ for at least $30 \mathrm{~d}$ in order to allow time for the body dimensions to stabilize. At least 10 to 15 larvae from each sample were randomly chosen and measured for standard length (L or notochord length) to the nearest $0.1 \mathrm{~mm}$ with the vernier scale of a compound microscope. Four other morphometric characters were measured to the nearest $0.01 \mathrm{~mm}$ with an ocular micrometer: anal body depth (ABD), the dorsal-ventral depth at the anus, excluding the gut; pectoral body depth (PBD), measured at the pectoral girdle, including the gut; head width (HW), measured across the dorsal surface of the head, including the eyeballs; and eye diameter (ED), always measured along the anterior-posterior axis of the eye. Dry weight (W) was measured to the nearest $\mu \mathrm{g}$ by rinsing a larva in freshwater, drying it at $60^{\circ} \mathrm{C}$ for $24 \mathrm{~h}$, and weighing the residue with an electrobalance.

The dimensions of the sea-caught plankton-net larvae were corrected for shrinkage or expansion caused by capture in towed nets using Gompertz models calibrated for Pacific herring larvae by McGurk (1985b). The lengths of the sea-caught night-light larvae were not corrected for net capture.

Starvation mortality. Condition of the herring larvae was estimated from the morphometric data using a multivariate condition factor McGurk (1985a),

$$
\begin{array}{r}
\mathrm{CF}=14.191-4.389 \ln \mathrm{L}+2.184 \ln \mathrm{ABD}+2.197 \ln \mathrm{PBD}- \\
12.331 \ln \mathrm{HW}+3.770 \ln \mathrm{ED}+0.419 \ln \mathrm{W} .
\end{array}
$$

CF classifies a Pacific herring larvae as feeding or starving primarily on the width of the head and, secondarily, on the depth of the body. Both variables shrink with starvation and expand with feeding. CF can only be calculated for non-yolk-sac larvae, and it classifies as starving those fish that are both reversibly and irreversibly starving. $C F<0$ identify feeding larvae and $C F>0$ identify reversibly and irreversibly starving larvae. The fraction of a cohort of larvae that was classified as starving at age $t$ was

$$
\mathrm{f}_{\mathrm{s}}(t)=\sum\left(\frac{\mathrm{f}_{\mathrm{s}}(t, a) N(t, a)}{N(t, a)}\right)
$$

where $f_{s}(t)=$ fraction of non-yolk-sac herring larvae at age $t$ classified as starving; $f_{s}(t, a)=$ fraction of larvae at sampling Stn $a$ and age $t_{i}$ and $N(t, a)=$ density of herring larvae measured at Stn $a$ and age $t$.

If all the larvae classified as starving at age $t$ are assumed to be irreversibly starving, then they will all be dead within the time period $t_{\mathrm{s}}$, defined as the number of days between the entry of a larva into a state of starvation and its death by irreversible starvation. In 
this case the instantaneous daily mortality rate, $M_{5}(t)$ $\left(d^{-1}\right)$ is defined as

$$
M_{\mathrm{s}}(t)=-\ln \left[1-\frac{\mathrm{f}_{\mathrm{s}}(t)}{t_{\mathrm{s}}}\right]
$$

However, Eq. (8) is not strictly correct for the present case because not all of the larvae classified as starving by $\mathrm{CF}$ are irreversibly starving, some will recover and reenter the feeding class. Thus, $\mathrm{f}_{\mathrm{s}}(t)$ must be reduced by the instantaneous daily rate of recovery, $U\left(\mathrm{~d}^{-1}\right)$, of reversibly starving larvae, i.e.

$$
M_{\mathrm{s}}(t)=-\ln \left[1-\frac{\mathrm{f}_{\mathrm{s}}(t) \exp (-U)}{t_{\mathrm{s}}}\right]
$$

Eq. (9) was used in this study to estimate the actual rate of mortality due to starvation. The primary difference between this formulation of $M_{\mathrm{s}}$ and those used by Hewitt et al. (1985) and Theilacker (1986) is that their histological and morphological techniques could distinguish between dying, starving, recovering and healthy fish. Thus, they used the arithmetic equivalent of Eq. (8).

The number of days from complete absorption of the yolk to irreversible starvation of Pacific herring larvae is $7.0 \mathrm{~d}$ at $8^{\circ} \mathrm{C}$ and $6.0 \mathrm{~d}$ at $10^{\circ} \mathrm{C}$ (McGurk 1984). Since this spans the temperature range encountered by wild herring in Bamfield Inlet in 1980 and 1981, the average $t_{\mathrm{s}}$ for the Bamfield Inlet cohorts was assumed to be a constant $6.5 \mathrm{~d}$. This assumption is supported by Yin \& Blaxter's (1987) work showing that the time to irreversible starvation for Atlantic herring larvae aged 36 to $60 \mathrm{~d}$ is also 6 to $7 \mathrm{~d}$.

The rate at which the reversibly starving fish recovered, $U$, was estimated by subtracting the average rate at which starving fish were expected to die if all the larvae in the starving category were assumed to be irreversibly starving, i.e. Eq. (8), from the rate at which $\mathrm{f}_{\mathrm{s}}(t)$ decreased with age (the sum of $M_{\mathrm{s}}$ and $U$ ).
The latter rate was equal to the slope of the regression of In $f_{s}(t)$ on $t$, using only the data on the right-hand limb of the plot of $\ln f_{s}(t)$ on $t$.

\section{RESULTS}

\section{Cohorts}

A total of 197 plankton-net samples and 36 nightlight samples were taken in 1981-1982, of which 176 and 36 , respectively, contained at least 1 herring larva. Seven cohorts were identified: Cohorts 1,2 and 3 in 1981, and Cohorts 4, 5,6 and 7 in 1982. Cohorts 1, 4 and 7 were each represented by only a few larvae and so they were excluded from any further analysis. Lengthfrequency plots, hatching dates, and the curves of growth in length and dry weight of Cohorts 2, 3, 5 and 6 were described by McGurk (1987a).

\section{Net evasion}

Plankton-net catches of newly-hatched larvae are judged to be reasonably accurate indices of abundance because the greatest concentrations of newly-hatched and mid-stage Pacific herring larvae are usually found within the upper $10 \mathrm{~m}$ of the water column (Stevenson 1962, S. Robinson \& M. St. John, Oceanography Department, University of British Columbia, pers. comm.), and because most ( $73 \%$ ) of the plankton-net samples for this study were taken at night when herring larvae of all ages actively migrate into the upper $10 \mathrm{~m}$ to feed (Blaxter \& Hunter 1982).

However, catches of mid-and late-stage larvae probably underestimated true population abundance because of net evasion, particularly during day tows. Fig. 2 shows that larvae longer than $18 \mathrm{~mm}$ were

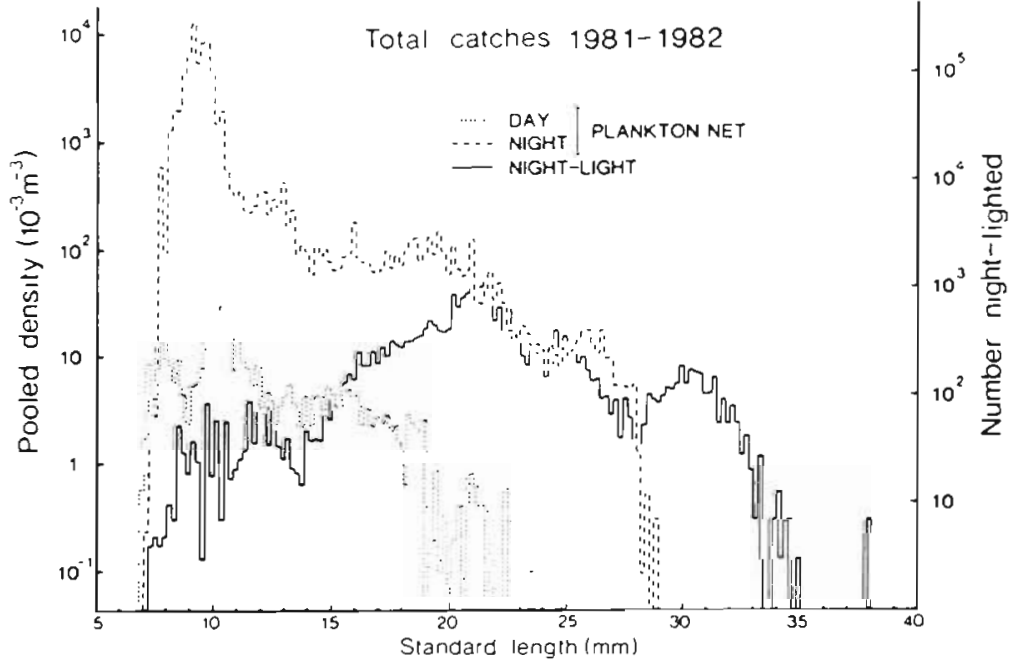

Fig. 2. Clupea harengus pallasi. Pooled densities of plankton-net catches of herring larvae taken during the day $(\cdots, \cdot)$ and the night $(-\cdots)$, and pooled numbers of night-lighted larvae (-), plotted against length in $0.2 \mathrm{~mm}$ bins 
caught in greater relative numbers by night tows than by day tows, indicating that daylight enabled herring larvae of this size to detect and evade towed plankton nets.

An equation to correct day plankton-net catches for net evasion was derived by first caculating the ratio of night to day catches for 7 pairs of plankton net catches taken at the same station within 24 h of each other. Only pairs with non-zero catches were used. The Intransformed ratios were regressed on the mean lengths of the herring larvae, $\overline{\mathrm{L}}$, (Fig. 3) to give a correction

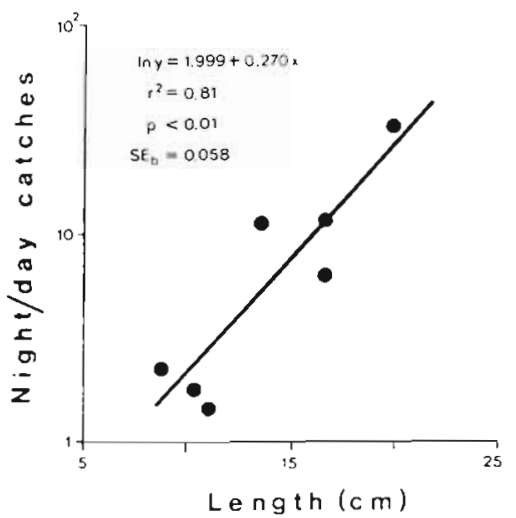

Fig. 3. Clupea harengus pallasi. Regression of ln-transformed ratio of night to day plankton net catches against mean length. Catches were taken at the same station within $24 \mathrm{~h}$ of each other

equation for day plankton net catches of larvae 7.9 to $25.0 \mathrm{~mm}$ long

$$
\begin{gathered}
\ln (\operatorname{corrected} N)= \\
\ln (\text { observed } N)-1.999+0.270 \overline{\mathrm{L}}
\end{gathered}
$$

A comparison of night plankton-net catches with night-light catches shown in Fig. 2 also shows that the former begins to underestimate true population abundance at lengths greater than 25 to $30 \mathrm{~mm}$. No correction for this factor was applied to the night plankton net catches because the great majority of larvae captured in this study were less than $25 \mathrm{~mm}$ long. In any case, ratios of night plankton-net catches to night-lighted catches cannot be utilized because of dissimilar units.

\section{Advection-diffusion-mortality models}

Only Cohorts 2 and 6 were fit by models that were significant at the $5 \%$ level and so only these 2 cohorts will be discussed further (Table 1).

Cohort 2:

$$
\begin{aligned}
& \ln N(y, x, t)= \\
& \quad \ln \left(\frac{C}{4 \pi H K_{y}}\right)-\ln t-\frac{\left(y-y_{0}-v t\right)^{2}}{4 K_{y} t}-Z t
\end{aligned}
$$

Table 1. Clupea harengus pallasi. Parameter values ( \pm 1 SD) of the advection-diffusion-mortality models. $R_{\mathrm{a}}^{2}$ : adjusted coef-

\begin{tabular}{|c|c|c|c|}
\hline \multirow{2}{*}{\multicolumn{2}{|c|}{ Parameter }} & \multicolumn{2}{|c|}{ Cohort } \\
\hline & & 2 & 6 \\
\hline \multirow{3}{*}{ In } & $C$ & \multirow[b]{3}{*}{$10.368 \pm 0.597$} & \multirow{3}{*}{$13.159 \pm 0.767$} \\
\hline & $4 \pi H \backslash K_{x} K_{y}$ & & \\
\hline & & & \\
\hline \multirow{2}{*}{$\ln$} & $C$ & & \\
\hline & $\overline{4 \pi H K_{\gamma}}$ & & \\
\hline$K_{x}$ & & & $0.477 \pm 0.315$ \\
\hline$K_{y}$ & & $0.080 \pm 0.038$ & $0.307 \pm 0.048$ \\
\hline \multicolumn{4}{|l|}{$x_{0}$} \\
\hline \multicolumn{2}{|l|}{$u$} & & \\
\hline \multicolumn{2}{|l|}{$y_{0}$} & $-0.0611 \pm 0.889$ & \\
\hline \multicolumn{2}{|l|}{ V } & $0.148 \pm 0.046$ & \\
\hline \multicolumn{2}{|l|}{$Z$} & $0.023 \pm 0.026$ & $0.157 \pm 0.035$ \\
\hline \multicolumn{2}{|l|}{$R_{a}^{2}$} & 0.37 & 0.56 \\
\hline \multirow{2}{*}{\multicolumn{2}{|c|}{$n$}} & 66 & 44 \\
\hline & & $0.01<p<0.05$ & $p<0.01$ \\
\hline \multicolumn{2}{|l|}{$t$} & 55 & 37 \\
\hline
\end{tabular}
ficicnt of determination; $n$ : number of plankton-net catches; $t$ : maxinum age of citches; $p$ : statistical probability of the fit of the models to the plankton-net catches

Cohort 6:

$$
\begin{aligned}
& \ln N(y, x, t)= \\
& \quad \ln \left(\frac{C}{4 \pi H \sqrt{K_{x} K_{y}} t}\right)-\ln t-\frac{x^{2}}{4 K_{x} t}-\frac{y^{2}}{4 K_{y} t}-Z t .
\end{aligned}
$$

The densities predicted by the models and the measured densities of the 2 cohorts are compared graphically in Fig. 4.

The amount of variance explained by the 2 models, $R_{a}^{2}$, was $37 \%$ and $56 \%$ for Cohorts 2 and 6 , respectively (Table 1). These numbers were adjusted for the number of parameters in each model by Eq. (4) and (5); they are equivalent to standard coefficients of determination, $r^{2}$, of 0.42 and 0.60 , respectively. A dispersion model fit by Heath \& MacLachlan (1987) to densities of larval Atlantic herring captured west of the Outer Hebrides (Scotland) had higher $R^{2}$ (range: 0.60 to 0.81 ), but because they had low ratios of data (13 to 17 data points) to parameters (4) in their model the $R_{a}^{2}$ (range: 0.42 to 0.75 ) were much lower than the $R^{2}$. Thus, the $R_{a}^{2}$ measured in this study are on the low end of the range of $R_{a}^{2}$ available in the literature.

The variance in the density data that is not explained by the population models was not significantly correlated $(p>0.05)$ with age of larvae, time of day at which the tows were taken, maximum depth of tows or height of tide at the time of towing. The squared residuals of Cohort 2 are significantly correlated with age $(r=0.37$, $p<0.01$ ), but this correlation is suspect because it is entirely dependent on only 3 of the 66 data points. The 


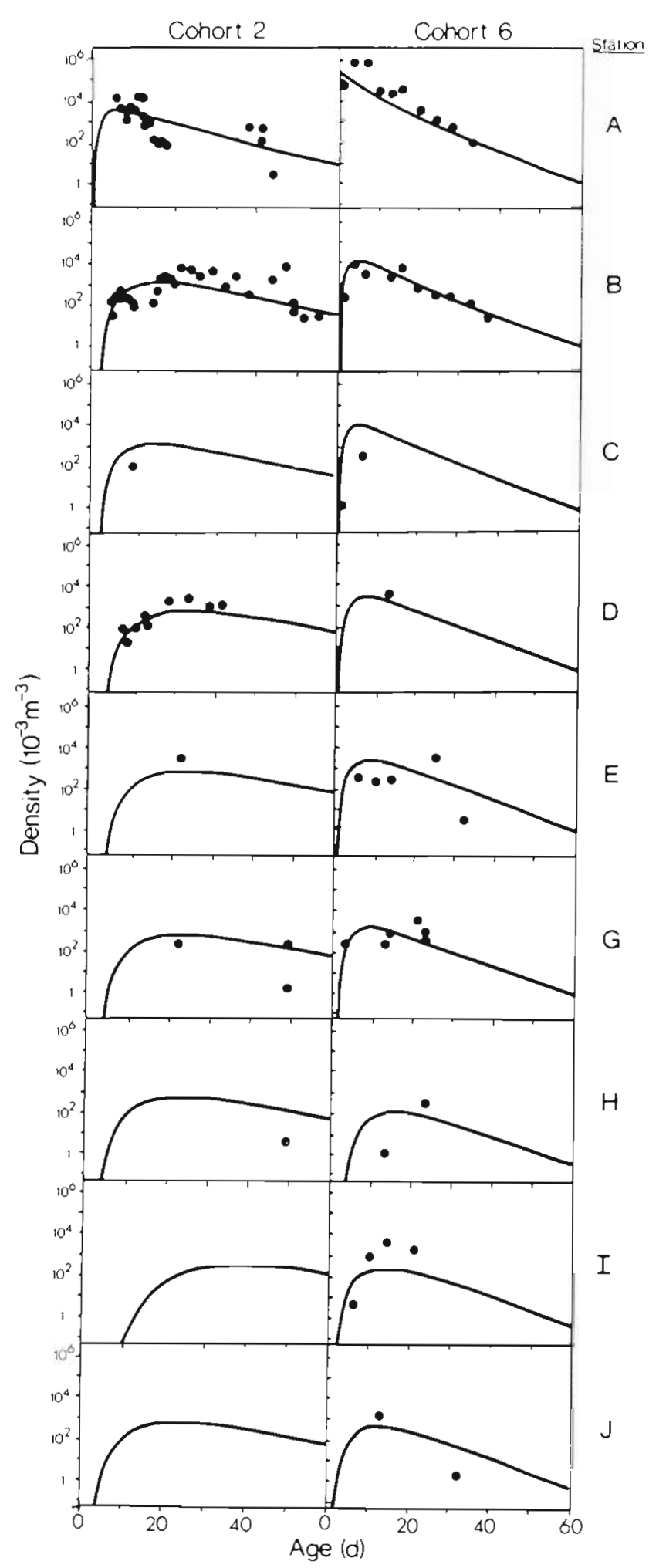

Fig. 4. Clupea harengus pallasi. Semi-logarithmic plot of plankton-net catches of herring larvae against age for Cohorts 2 and 6 taken in the Bamfield Inlet-Trevor Channel area in 1981 and 1982. Letters $A$ to $J$ identify plankton sampling stations. Curves are the catches predicted from the advectiondiffusion-mortality models (Eqs. 11 and 12) squared residuals of Cohort 6 are significantly correlated with hour of day $(r=-0.33,0.01<p<0.01)$, but this correlation must also be treated with caution because it disappears if only one of the 44 tows is removed and because it is a negative correlation, which is unlikely considering that night tows are certainly more accurate indices of abundance than day tows.

It is possible that the unexplained variance of Cohorts 2 and 6 may have been due to violations of the 2 major assumptions of the population models: that $Z$ is constant with age, and that $K_{x}$ and $K_{y}$ are constant with $x$ and $y$, respectively. This possibility was tested by rearranging $\mathrm{Eq}$. (11) to give

$\ln N+\ln t+\frac{\left(y-y_{0}-v t\right)^{2}}{4 K_{y} t}=\ln \left(\frac{C}{4 \pi H K_{y}}\right)-Z t$

$\ln N+\ln t+Z t=\ln \left(\frac{C}{4 \pi H K_{y}}\right)-\frac{1}{4 K_{y}} \cdot \frac{\left(y-y_{0}-v t\right)^{2}}{t}$

$\ln N+\ln t+\frac{\left(y-y_{0}-v t\right)^{2}}{4 K_{y} t}+Z t=\ln \left(\frac{C}{4 \pi H K_{y}}\right)$

and rearranging Eq. (12) to give

$$
\begin{gathered}
\ln N+\ln t+\frac{x^{2}}{4 K_{x} t}+\frac{y^{2}}{4 K_{y} t}=\ln \left(\frac{C}{4 \pi H \sqrt{K_{x} K_{y}}}\right)-Z t \\
\ln N+\ln t+\frac{x^{2}}{4 K_{x} t}+Z t= \\
\ln \left(\frac{C}{4 \pi H \sqrt{K_{x} \overline{K_{y}}}}\right)-\frac{1}{4 K_{y}} \cdot \frac{y^{2}}{t} \\
\ln N+\ln t+\frac{y^{2}}{4 K_{y} t}+Z t= \\
\ln \left(\frac{C}{4 \pi H \sqrt{K_{x}}} \overline{\overline{K_{y}}}\right)-\frac{1}{4 K_{x}} \cdot \frac{x^{2}}{t}
\end{gathered}
$$

Note that the righthand sides of Eqs. $(11 a, b, c)$ and $(12 a, b, c)$ are straight lines with intercepts of $\ln \left[C\left(4 \pi H K_{y}\right)^{-1}\right]$ or $\ln \left[C\left(4 \pi H \sqrt{K_{x} K_{y}}\right)^{-1}\right]$ and slopes of $Z$, $\left(4 K_{x}\right)^{-1}$ or $\left(4 K_{y}\right)^{-1}$. Eq. (11c) has no slope because diffusion along the $x$-axis was not included in the model for Cohort 2 due to its lack of statistical significance. If the 2 assumptions are correct, then plots of the lefthand side of each rearranged equation on its righthand side should be linear with the data falling evenly about the lines predicted by the models. If the 2 assumptions are not correct, then the data should not fall evenly about the predicted line but exhibit some residual pattern. Fig. 5 shows that the plots are substantially linear and patternless, which supports the major assumptions of the model.

In summary, the unexplained variance in the population data is higher, on average, than that reported by Heath \& MacLachlan (1987), but the causes of the 
Fig. 5. Clupea harengus pallasi. Population densities of Cohorts 2 and 6 transformed by the rearranged Eqs. $(11 \mathrm{a}, \mathrm{b}, \mathrm{c})$ and $(12 a, b, c)$ and plotted against $t$. $x^{2} t^{-1}, y^{2} t^{-1}$ and $\left(y-y_{0}-v t\right)^{2} t^{-1}$ Straight lines are the predictions of the models (Eqs. 11 and 12). Plots show that the assumptions of the populations models - a constant $Z$ with $t$, and a constant $K_{x}$ and $K_{y}$ with $x$ and $y$, respectively are validated by the linearity of the plots and the lack of residual pattern of the data
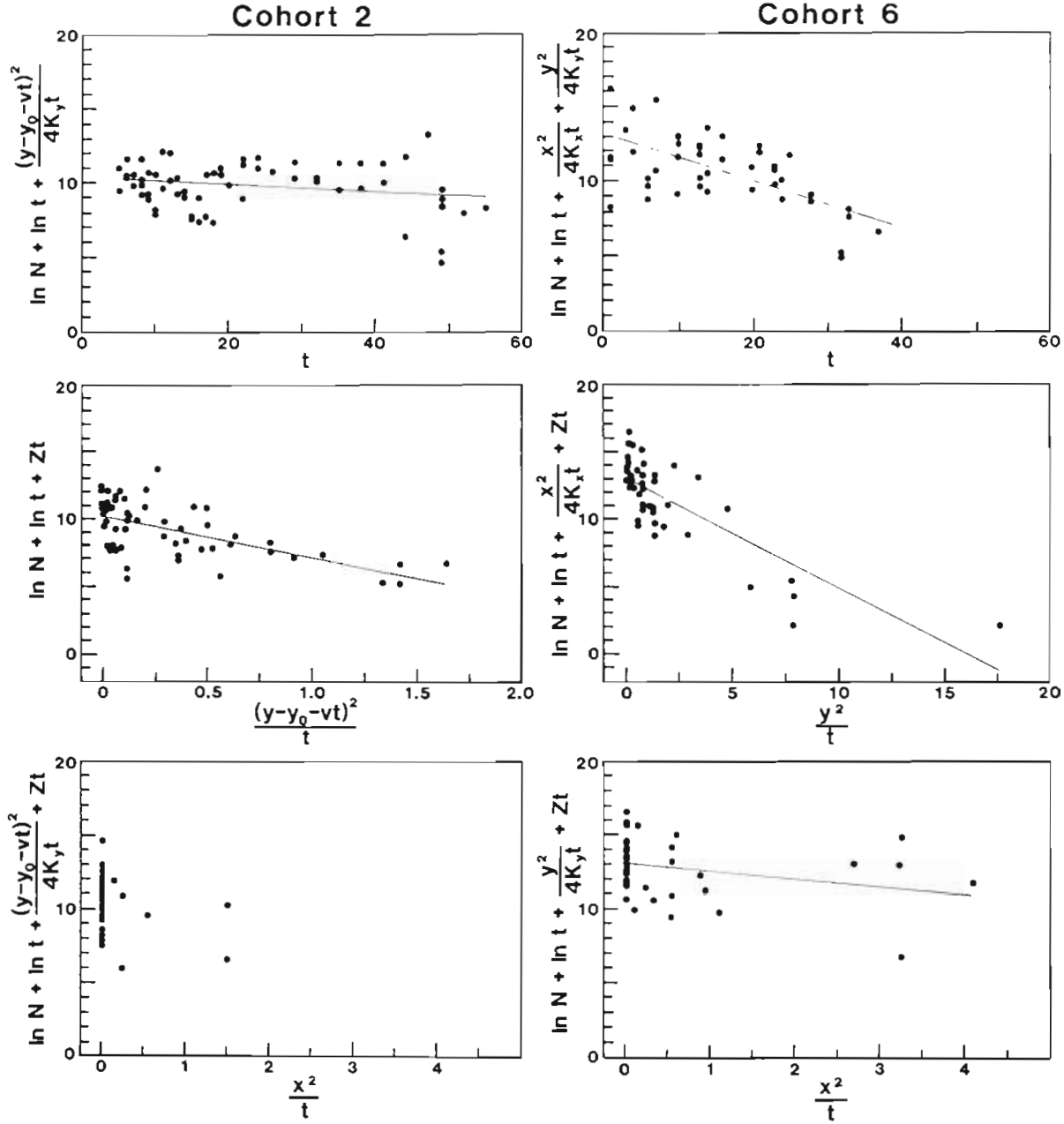

unexplained variance are not identified. The unexplained variance may be due to an interaction between the frequency of sampling in space and time and the spatial patchiness of the fish.

\section{Density at hatch $\left(\mathrm{CH}^{-1}\right)$}

The first parameter of Cohort 6 was significantly higher than that of Cohort 2 ( $t$-test: $p<0.001$ ) (Table 1). The number of newly-hatched larvae per unit volume, $C$, cannot be calculated from this parameter because depth $H$ is not known. Instead, the number of newlyhatched larvae per unit area, $\mathrm{CH}^{-1}$, was calculated for Cohorts 2 and 6 as $3.2 \times 10^{4} \mathrm{~km}^{-2}$ and $2.50 \times 10^{6} \mathrm{~km}^{-2}$, respectively. Therefore, Cohort 6 had an initial density 78 times higher than Cohort 2.

This result agrees well with observations of the extent of spawning of the 2 cohorts: the eggs of Cohort 6 were easily discovered because they covered several $100 \mathrm{~m}^{2}$ of the intertidal zone at the head of Bamfield Inlet in April 1982, but the eggs of Cohort 2 were never observed by this author, presumably because they were contained in a small patch that was entirely subtidal. Although Pacific herring eggs are usually deposited in the intertidal zone, sub-tidal spawning is not uncommon (Humphries \& Hourston 1978).

\section{Coordinates of hatch sites $\left(y_{0}, x_{0}\right)$}

The $y$-coordinate of the hatch site of Cohort 2 was not significantly ( $t$-test; $p>0.05$ ) different from zero (Table 1). This confirms that Cohort 2 hatched within the upper basin of Bamfield Inlet, but was not observed because it was a small sub-tidal spawning.

\section{Advection $(u, v)$}

The rates of advection in the y-axis, $v$, for Cohort 2 is by definition significantly higher than $v$ for Cohort 6 . One possible explanation for the difference in advection between years is that the rate of offshore move- 
ment of the low-salinity surface water was lower in March-May 1982 than March-May 1981 because rainfall was lower in 1982 than in 1981. The rainfall data shown in Fig. 6A, D support this hypothesis because the cumulative rainfall over the March-May period was almost twice as high in $1981,739.7 \mathrm{~mm}$, as in 1982 , $431.1 \mathrm{~mm}$. Fig. 6A, D shows that $70 \%$ of the total amount of rainfall that fell over March-May 1982 occurred before Cohort 6 larvae entered the water column.

The advection rates reported in this study are the lowest ever reported for herring larvae. Previously reported rates for Atlantic herring larvae have ranged from 1 to $3 \mathrm{~km} \mathrm{~d}^{-1}$ for larvae on Georges Bank (Wright \& Lough 1979 cited by Munk et al. 1986), to $3.4 \mathrm{~km} \mathrm{~d}^{-1}$ for larvae in the Buchan area of the North Sea (Munk et al. 1986), to $3.8 \mathrm{~km} \mathrm{~d}^{-1}$ for larvae off Whitby in the North Sea (Nichols et al. 1985 cited by Munk et al. 1986 ) and $5.8 \mathrm{~km} \mathrm{~d}^{-1}$ for larvae off the west coast of the Outer Hebrides Islands (Heath \& MacLachlan 1987). There are no pure estimates of advection for Pacific herring larvae available in the literature because all previous studies of dispersal, e.g. Stevenson (1962) and Alderdice \& Hourston (1985), did not separate advective from diffusive transport. The relatively low advec- tion of Bamfield Inlet herring larvae was most likely due to a combination of a lack of freshwater discharge into the Inlet, which meant a relatively low rate of flow of the surface low-salinity layer, and to the enclosed physiography of the region.

\section{Diffusion $\left(K_{x}, K_{y}\right)$}

$K_{y}$ and $K_{x}$ of Cohort 6 were not significantly different from each other ( $t$-test: $p>0.05$ ), but they were 3 to 6 times higher than $K_{y}$ of Cohort 2, a difference that is statistically significant (t-test: $p<0.05$ ) (Table 1). Higher diffusivity in 1982 than in 1981 suggests that turbulence in the upper layer of the water column was higher in the spring of 1982 than in the spring of 1981. Mixing of inshore waters is usually controlled by tides and wind events. Direct measurements of average tidal velocities in the area are not available, but they can be calculated from tide tables, if it is assumed that velocities are proportional to the average rate of change of water height over a tidal cycle. Examination of the average daily rate of change of water height due to tides shown in Fig. 6C, F indicates that there was little difference in its magnitude between 1981 and 1982

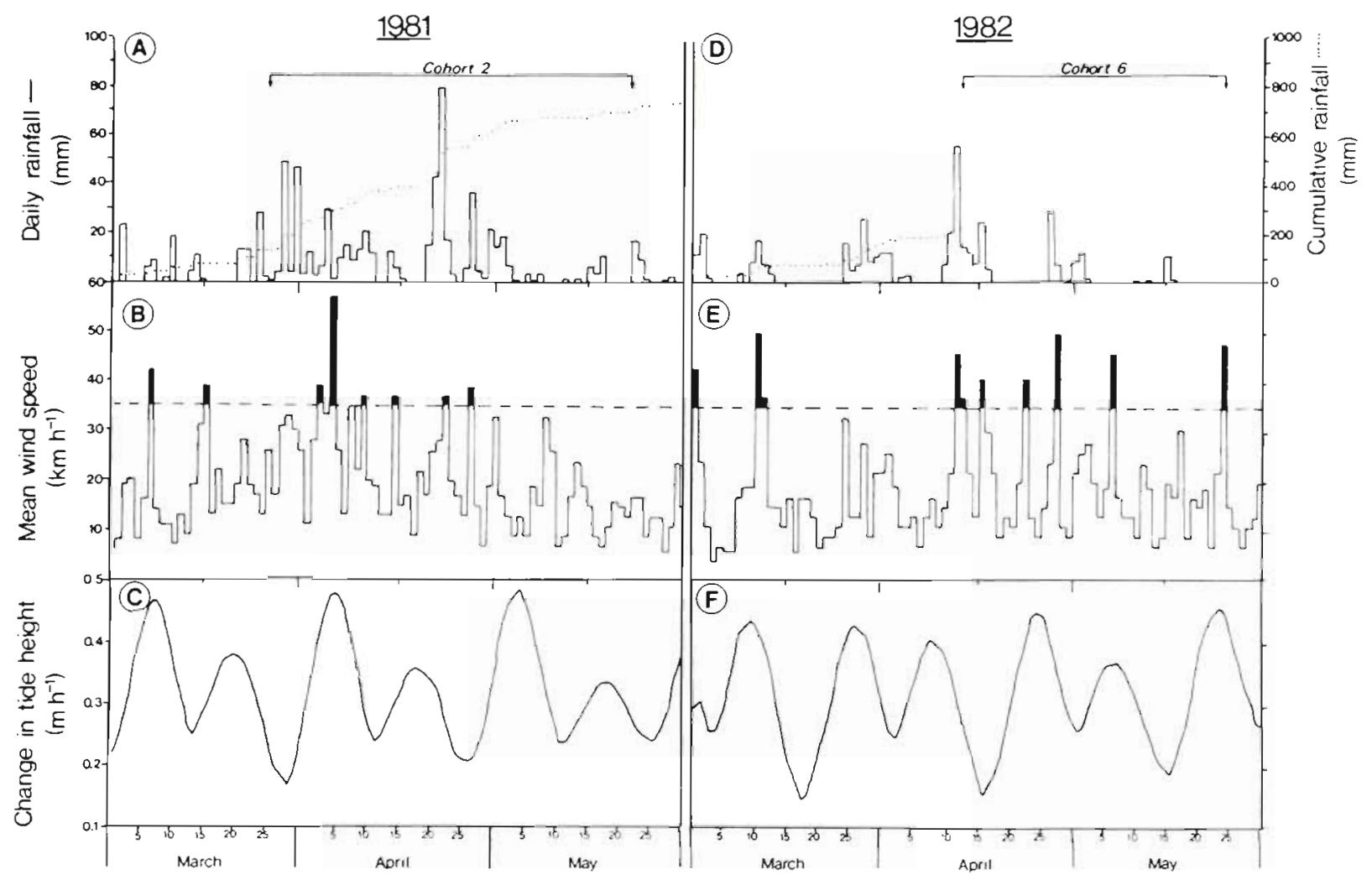

Fig. 6. Environmental variabies in the Bamfield Inlet area during March to May 1981 and 1982. (A, D) Daily and cumulative rainfall at Bamfield Inlet. ( $B$, E) Mean wind speed at Cape Beale Lighthouse. Filled bars identify wind events of speeds greater than $35 \mathrm{~km} \mathrm{~h}^{-1}$ (C, F) Mean rate of change of water height due to the semi-diurnal tides 
Fig. 7 Percent of the time that the mean wind speed (A) and the average rate of change of water height with time over 1 tidal cycle $(B)$ exceeded a range of values for the periods in which Cohorts 2 and 6 were in the plankton-net catches
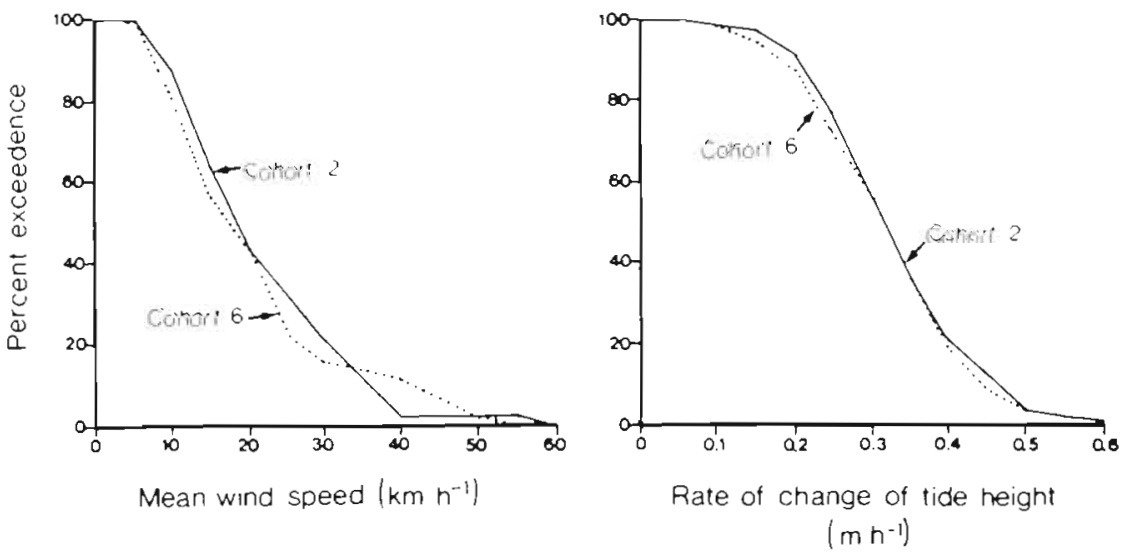

This observation is supported by an exceedence analysis of the rate of change of tide height. Percent exceedence is defined as the percent of the total time that a variable, in this case the rate of change of tide height, exceeds a specified value. Thus, percent exceedence is always $100 \%$ at a rate of zero and $0 \%$ at the maximum observed rate and a curve can be drawn that describes how percent exceedence changes over this range of rates. Fig. $7 \mathrm{~B}$ shows that the curves of percent exceedance of the 2 cohorts were almost identical, indicating that there were no substantial differences between the tidal regimes experienced by Cohorts 2 and 6 .

However, there was a difference between the 2 yr in the frequency of high-speed wind events. Fig. $7 \mathrm{~A}$ shows that the percent exceedence of the wind speeds diverged sharply for speeds greater than $35 \mathrm{~km} \mathrm{~h}^{-1}$. with Cohort 6 having percent exceedences ca 5 times higher than Cohort 6 at $40 \mathrm{~km} \mathrm{~h}^{-1}$. Wind speeds greater than $35 \mathrm{~km} \mathrm{~h}^{-1}$ were obviously more frequent and more intense in 1982 than in 1981 (Fig. 6B, E).

The diffusivities measured in this study are among the lowest reported for pelagic fish eggs and larvae (Koslow et al. 1985, Munk et al. 1986, Heath \& MacLachlan 1987). There are at least 3 possible reasons for the low diffusivities. First, the Bamfield Inlet-Trevor Channel area is enclosed and sheltered, whereas all other studies have been conducted in open seas. Presumably a sheltered site is not susceptible to the same kind of wave-and wind-generated turbulence that occurs in open seas. Second, the scale of diffusion of this study was small compared to most other studies, and turbulent diffusion has been shown to increase with increasing scale in the sea. Okubo (1971) showed that the coefficient of Fickian diffusion of a dye-release experiment that is assumed to be radially symmetrical, i.e. $K_{r c}=\sqrt{K_{x} K_{y}}=\sigma_{x} \sigma_{y} / 2 t$ where $\sigma_{x}^{2}$ and $\sigma_{y}^{2}$ are the horizontal variances in the $x$-and $y$-axes respectively, increases with the scale of diffusion, $\ell=3 \sigma_{r c}=6 \sigma_{x} \sigma_{y}$, according to the empirical relationship $K_{r c}=$ $0.0103 \ell^{1.15}$, where $K_{\text {rc }}$ has units of $\mathrm{cm}^{2} \mathrm{~s}^{-1}$ and $\ell$ has units of $\mathrm{cm}$. The reason for this relationship is presumed to be the incorporation of larger-scale turbulence such as larger-scale eddies and current patterns with increasing scale of diffusion. The difference between the $K_{r c}$ of this study and those of other studies is greatly reduced if the scale effect is removed by dividing $K_{I C}$ by Okubo's (1971) empirical relationship

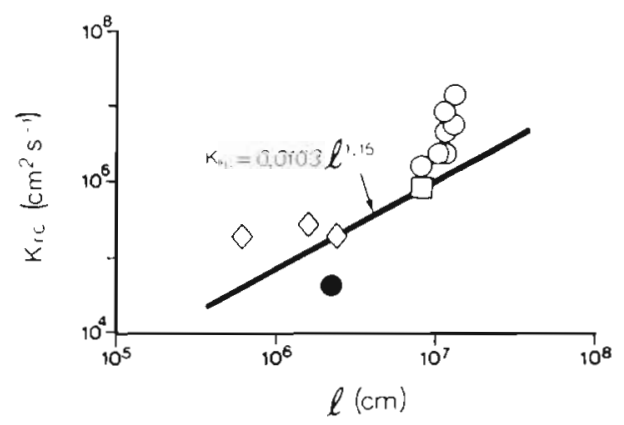

Fig. 8. Double logarithmic plot of the coefficient of radial diffusion. $K_{r c}$, on scale of diffusion, $($ for population of pelagic fish eggs and larvae: $(\bullet)$ Clupea harengus pallasi larvae, this study; (1) Melanogrammus aeglefinus eggs (Koslow et al. 1985); ( $\square$ ) C. harengus harengus larvae (Munk et al. 1986). (১) C. harengus harengus larvae (Heath \& MacLachlan 1987). The line is Okubo's (1971) empirical relation $K_{r C}=0.0103 t^{\text {t. is }}$ for dye-release experiments in the sea

(Fig. 8). Third, the Bamfield Inlet larvae were sampled over a longer age range than the eggs and larvae of all previous studies. Since Pacific herring larvae begin to school at age $25 \mathrm{~d}$ (Marliave 1980, McGurk 1987b), the scale-corrected diffusivity of larvae should decrease continuously with increasing larval age. In order to test this idea, $K_{r c}\left(0.0103 \ell^{1.15}\right)^{-1}$ of Fig. 8 was plotted on age after both variables were transformed with natural logarithms. The 2 variables are significant correlated $(r=-0.76 ; p<0.01$ ) (Fig. 9), supporting the concept that diffusivity of herring larvae decreases with age. 


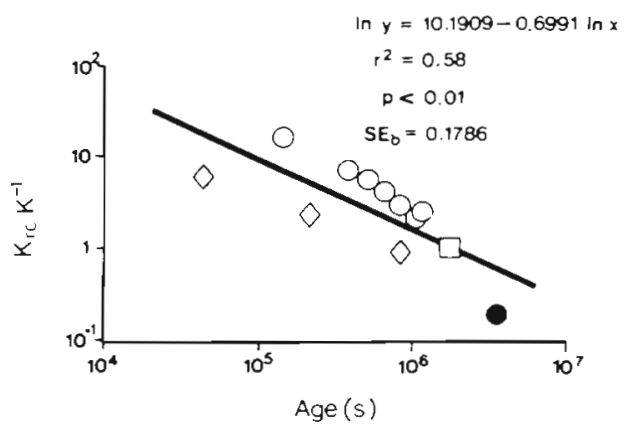

Fig. 9. Double logarithmic plot of scale-adjusted radial diffusion on age for pelagic fish eggs and larvae. Symbols as in Fig. 8

\section{Total mortality $(Z)$}

$Z$ of Cohort 6 was more than 6 times larger than $Z$ of Cohort 2 , a difference that is highly significant ( $t$-test: $p<0.001$ ) (Table 1). $Z$ of Cohort 2 is not significantly different $(p>0.05)$ from zero, but $Z$ of Cohort 6 is significantly higher $(p<0.001)$ than zero. Thus, the major contrast of this study that requires explanation is the great difference in total mortality between Cohort 6 and Cohort 2 .

The total mortality rates measured in this study are much lower than those measured by Stevenson (1962) in Barkley Sound, but they are comparable to those measured by Iizuka (1966) in Akkeshi Bay, Japan. They fall within the range of mortalities measured for Atlantic herring larvae by other investigators, 0.02 to $0.46 \mathrm{~d}^{-1}$ (Das 1968, Dragesund \& Nakken 1971, 1973, Graham \& Chenoweth 1973, Lough et al. 1981, Henderson et al. 1984, Munk et al. 1986. Heath \& MacLachlan 1987). The mortality rate for Cohort 2 is the lowest yet measured for Pacific herring larvae, but it is comparable with the lowest rate of mortality yet measured for Atlantic herring larvae, $0.026 \mathrm{~d}^{-1}$ by Heath \& MacLachlan (1987).

\section{Starvation mortality $\left[M_{\mathrm{s}}(t)\right]$}

A total of 1025 herring larvae were measured for 5 morphometric dimensions and dry weight: 570 from Cohort 2 and 455 from Cohort 6 . Most of the starving larvae were first-feeders 0 to $20 \mathrm{~d}$ old and more than $98 \%$ of them were captured in Bamfield Inlet at Stns A and $B$ (Table 2). The fact that almost all starving Pacific herring larvae were found within a relatively smail area near the hatch sites at the head of Bamfield Inlet supports the findings of other authors concerning the patchy nature of starving larvae. O Connell (1980) found that most of the emaciated northern anchovy Engraulis mordax larvae that he collected in the South-
Table 2. Clupea harengus pallasi. Percent of total density of starving larvae that were captured at a plankton-net station. Dashes indicate no samples captured during the time period of incipient starvation ( 0 to $30 \mathrm{~d}$ )

\begin{tabular}{|lccc|}
\hline $\begin{array}{l}\text { Plankton-net } \\
\text { station }\end{array}$ & $\begin{array}{c}\text { y-axis } \\
\text { coordinate }\end{array}$ & 2 & 6 \\
\hline A & & 91.60 & 98.70 \\
B & 0.9 & 7.24 & 1.07 \\
C & 2.8 & 0.26 & 0.01 \\
D & 2.8 & 0.90 & - \\
E & 4.2 & 0.00 & 0.01 \\
G & 4.2 & 0.00 & 0.03 \\
H & 4.2 & - & 0.00 \\
I & 4.2 & - & 0.17 \\
J & 6.9 & - & 0.02 \\
\hline
\end{tabular}

ern California Bight in March 1977 were from a few nearshore tows, indicating 'patches' of starving larvae. Theilacker (1986) reported that $70 \%$ of jack mackerel Trachurus symmetricus larvae captured on offshore banks of the California Bight were classified as starving by histological and morphometric means, but that only $12 \%$ of fish captured near islands and banks were starving.

Trajectories of the fraction of starving larvae, $f_{s}(t)$, with age were similar between the 2 cohorts (Fig. 10); $\mathrm{f}_{\mathrm{s}}(t)$ rose from zero at hatch to a maximum between the ages of 4 and $9 \mathrm{~d}$ as the first-feeding larvae entered the

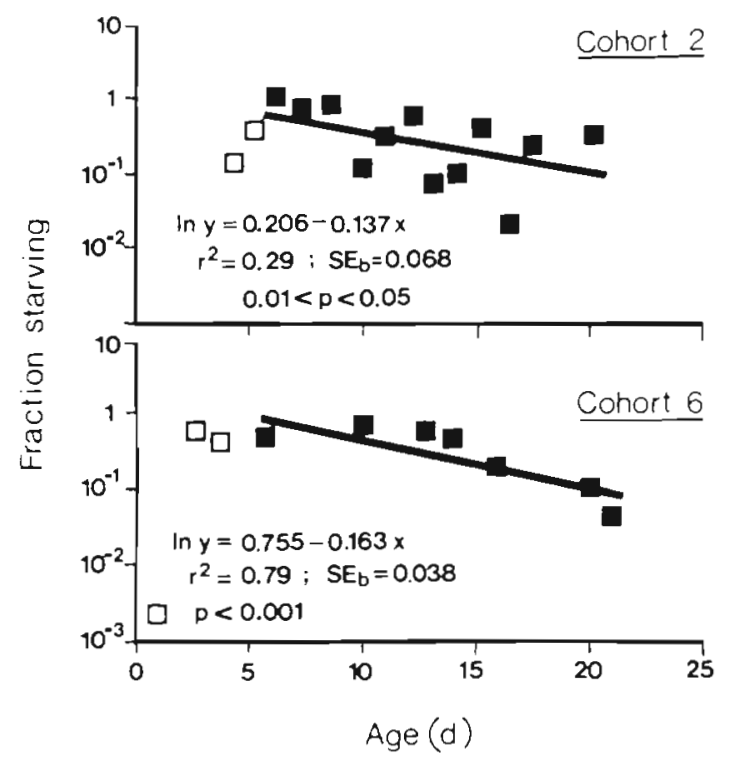

Fig. 10. Clupea harengus pallasi. Plots of the In-transformed fraction of herring larvae classified as starving against age. Rate of loss of starving larvae with age is the sum of mortality due to irreversible starvation, $M s$, and the rate of recovery of reversibly starved larvae, $U$. Only the solid symbols were included in the regression 
states of reversible and irreversible starvation, and then decreased to zero by age 20 to $26 \mathrm{~d}$ as the reversibly starving larvae recovered and the irreversibly starving larvae died. The age range in which starving larvae occur is similar to the range of ages of irreversible starvation of Pacific herring measured by McGurk (1984) for larvae starved in laboratory aquaria. It is similar to the age range in which negative growth of wild Pacific herring larvae of the Strait of Georgia was observed by Robinson \& Ware (1988) using RNA/DNA ratios of the fish. This indicates that the morphometric condition factor is measuring an aspect of true physical condition of the fish.

The rate of loss of herring larvae from the starving category was the slope of a linear regression of $\ln f_{s}(t)$ on $t$ for the righthand limbs of the plots in Fig. 10. This rate, which is the sum of mortality due to irreversible starvation, $M_{s}$ and the rate of recovery of the reversibly starving larvae, $U$, was not significantly different ( $t$ test, $p>0.05$ ) between the 2 cohorts (Table 3 ).

Table 3. Clupea harengus pallasi. Total rate of loss of herring larvae from the starving category $( \pm 1 \mathrm{SD})$, divided into 2 components: the expected mean $( \pm 1 \mathrm{SD}$ ) rate of loss due to irreversible starvation, $M \mathrm{~s}$, if all herring larvae classified as starving were assumed to be irreversibly starving, and the minimum rate of loss due to recovery of reversibly starving larvae, $U$, which remains after subtraction of expected Ms from the total rate of loss

\begin{tabular}{|lcc|}
\hline $\begin{array}{c}\text { Loss rate } \\
\left(\mathrm{d}^{-1}\right)\end{array}$ & \multicolumn{2}{c|}{ Cohort } \\
\hline$M s+U$ & $0.137 \pm 0.236$ & 6 \\
\hline Expected $M s$ & $0.038 \pm 0.028$ & $0.058 \pm 0.101$ \\
$U$ & 0.099 & 0.105 \\
\hline
\end{tabular}

The mean expected $M_{\mathrm{s}}$ ( $\pm 1 \mathrm{SD}$ ) for the 4 to $26 \mathrm{~d}$ age interval, calculated assuming that all larvae classified as starving were actually irreversibly starving and that they had an average of $6.5 \mathrm{~d}$ from entry into this condition to death, ranged from $0.038 \pm 0.028 \mathrm{~d}^{-1}$ for Cohort 2 to $0.058 \pm 0.069 \mathrm{~d}^{-1}$ for Cohort 6 (Table 3). Subtracting this number from the total rate of loss provides a minimum estimate of $U$ ranging from 0.099 $\mathrm{d}^{-1}$ for Cohort 2 to $0.105 \mathrm{~d}^{-1}$ for Cohort 6. Thus, a minimum of 10 to $11 \%$ of the herring larvae classified as starving recovered each day and re-entered the feeding category.

The actual rate of mortality due to irreversible starvation was calculated according to Eq. (9), rather than Eq. (8), because it was necessary to adjust the fraction of larvae classified as starving in each day for the percentage of that fraction which recovered and re-entered the feeding class.
A comparison of total and starvation mortality rates between cohorts indicates that starvation alone is not a sufficient explanation for the differences in $Z$ between Cohorts 2 and 6 (Fig. 11). Although there was substantial coincidence between the average value of actual

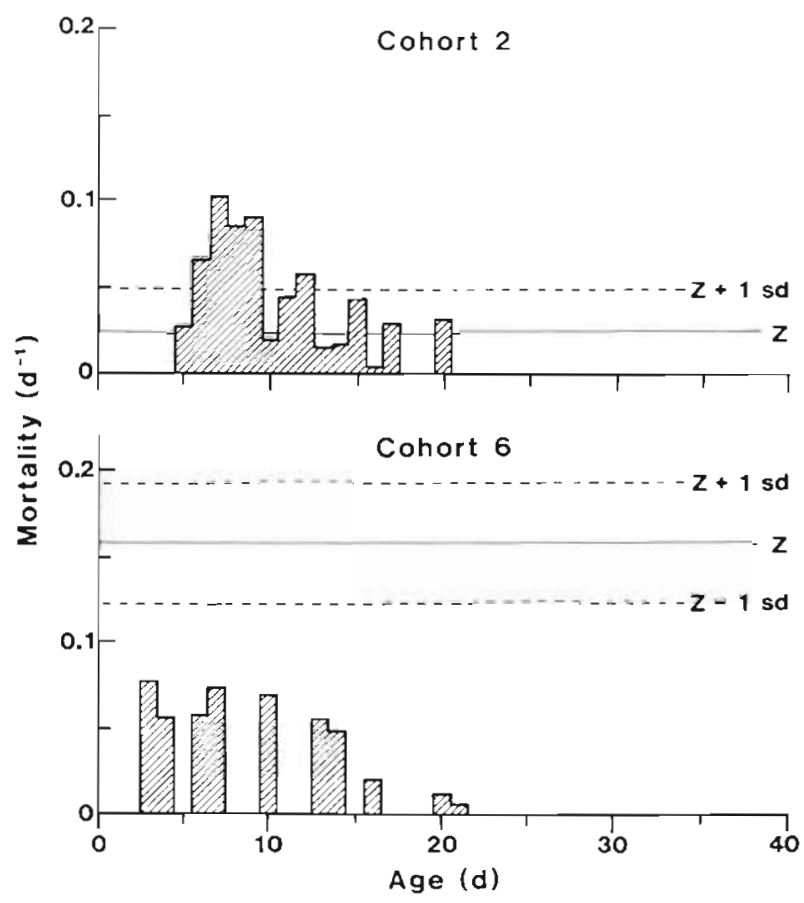

Fig. 11. Clupea harengus pallasi. Plots of starvation mortality, $M_{\mathrm{s}}(t)$, against age for Cohorts 2 and $6 . M_{\mathrm{s}}(t)$ was estimated from the fraction of the larvae at age that were classified as starving with a morphometric condition factor, after correcting for the loss of starving larvae due to the recovery of reversibly starving larvae (Eq. 9). Solid lines are total mortality, $Z$

$M_{s}(t)$ and $Z$ over the 0 to $30 \mathrm{~d}$ age interval of Cohort 2 , suggesting that most of the total mortality over the 5 to $20 \mathrm{~d}$ age range in this cohorts may have been due to starvation, $M_{\mathrm{s}}(t)$ was, on average, only half the level of $Z$ over the 0 to $20 \mathrm{~d}$ age range of Cohort 6 . The lack of correlation between $Z$ and average $M_{s}(t)$ suggests that agents of mortality other than starvation were more important than starvation, at least in Cohort 6. The single most important of these other agents is presumed to be predation.

\section{DISCUSSION}

This study is essentially a comparison between a large cohort (Cohort 6) with high rates of offshore dispersal and total mortality, and a small cohort (Cohort 2) with lower rates of offshore dispersal and total mortality. Although starving larvae were found in both cohorts, the magnitude of starvation mortality did not vary with total mortality. This suggests that the relative 
importance of starvation to predation varied between years and between cohorts and that it was controlled or modified by offshore dispersal and population density.

This conclusion depends crucially on the accuracy with which $Z$ and $M_{s}$ were measured. The major assumptions that were used to obtain $Z$ were a constant $Z$ with age and Fickian diffusion. The 2 assumptions followed from the constraints of the population model. Some form of combined diffusion-mortality modelling was essential to the analysis of the Bamfield Inlet data. Talbot (1977), Munk et al. (1986), Taggart \& Leggett (1987a) and Heath \& MacLachlan (1987) have emphasized the importance of measuring advective and diffusive dispersal as a necessary component of the process of measuring $Z$. For example, Taggart \& Leggett (1987a) demonstrated that the immigration of capelin larvae into their study area was responsible for between 32 and $66 \%$ of the apparent $Z$, and that without careful measurement of advection and diffusion and correction for these 2 processes their estimates of $Z$ would have been artificially high. This report is the first to partition the variance in population densities of Pacific herring larvae into a component due to mortality and components due to advective and diffusive transport. Neither Stevenson (1962) in British Columbia or Iizuka (1966) in Japan made corrections for the loss of larvae from dispersal, both assuming that it was of minor importance relative to losses due to mortality. It is now clear that such an assumption is no longer tenable and that some form of population. modelling that incorporates advective and diffusive transport is always necessary for the production of reliable estimates of $Z$.

A constant $Z$ was chosen because it was the simplest kind of mortality rate and therefore the easiest to incorporate in a dispersion model, because the population densities shown in Fig. 4 do not exhibit the sharp changes in magnitude that would be expected if $Z$ changed substantially with age, and because if $M_{s}(t)$ is a large component of $Z$, then the magnitude of $Z$ will still reflect its influence. Its choice is supported by the plots in Fig. 5, which show that $Z$ is well-described as constant with age, and by the fact that all previous authors who measured mortality in Pacific (Stevenson 1962, Iizuka 1966) and Atlantic herring larvae (Das 1968, Dragesund \& Nakken 1971, 1973, Graham \& Chenoweth 1973, Lough et al. 1981, Henderson et al. 1984, Munk et al. 1986, Heath \& MacLachlan 1987) reported or assumed that, on average, it was constant with age. It is possible that a relatively constant $Z$ over the larval stage is a feature of the life history of herring. On the other hand, it can be argued that since $M_{\mathrm{s}}(t)$ changes with age any attempt to compare $Z$ and $M_{\varsigma}(t)$ should involve the calculation of an age-dependent $Z$ such as was calculated by Hewitt et al. (1985) and Leak
\& Houde (1987). I note that neither of these authors measured diffusion or advection simultaneously with $Z$ from the densities of larvae. In fact, all studies of the population dynamics of fish eggs and larvae in which both $Z$ and $K$ have been measured have assumed a constant $Z$ (Koslow et al. 1985, Munk et al. 1986, Heath \& MacLachlan 1987). There is obviously a need for the development of an analytical advection-diffusion-mortality model that incorporates a time-varying $Z$.

The plots of transformed density on $x^{2} t^{-1}, y^{2} t^{-1}$ and $\left(y-y_{0}-v t\right)^{2} t^{-1}$ in Fig. 5 show that Fickian diffusion was appropriate for modelling the transport of Bamfield Inlet herring larvae. It is unlikely that the herring larvae were actually transported as if they were passive Brownian particles, as is assumed by Fickian diffusion, because Pacific herring larvae begin to school by the age of $25 \mathrm{~d}$ and possess completely developed schooling behavior at age $60 \mathrm{~d}$ (Marliave 1980. McGurk 1987b), and because studies on the dispersal of Atlantic herring larvae in estuaries by Graham (1972), Able (1978), Fortier \& Leggett $(1982,1983)$, Powles et al. (1984) and Henri et al. (1985), and on continental shelves by Iles \& Sinclair (1982) and Sinclair \& Iles (1985) have shown that herring larvae are not usually passively distributed by water currents. Instead, they show a tendency to maintain themselves in 'retention zones'. However, until the assumption of Fickian diffusion is demonstrated to be untenable by an analysis similar to that presented in Fig. 5, it remains the simplest and most convenient method of modelling diffusion of fish eggs and larvae.

Since the major conclusion of this report hinges on the characterization of Cohort 2 as a low-diffusion/lowmortality population and Cohort 6 as a high-diffusion/ high-mortality population, it is vital to know how sensitive the population models are to alternate partitions of the variance into diffusion and mortality components. Do other models exist that assign very different ratios of diffusion to mortality, albeit at the cost of a reduction in the amount of explained variance? This question was investigated with an sensitivity analysis of the population model of Cohort 6, which exhibits the greatest sensitivity to fractional perturbations in parameter values because it has the largest parameters. Each of the 4 parameters of Eq. (12): $C H^{-1}, K_{x}, K_{y}$ and $Z_{1}$ was fixed at some fraction of its original value and the non-linear multiple regression program was rerun in order to obtain new estimates of the other 3 parameters. The analysis shown in Table 4 indicates that $\mathrm{CH}^{-1}$ is most sensitive to perturbations in $K_{y}$ and $Z$ and least sensitive to perturbations in $K_{x}$, but that $K_{x}, K_{y}$ and $Z$ are insensitive to changes in $\mathrm{CH}^{-1}$. In other words, the estimates of diffusion and mortality are independent of the initial hatching density of Cohort 6, a conclusion that holds for all of the 9 possible population models 
Table 4. Clupea harengus pallasi. Results of the sensitivity analysis of the population model of Cohort 6 as percentage changes in the parameters of the model for perturbations in individual parameters

\begin{tabular}{|c|c|c|c|c|}
\hline Parameter & $-50 \%$ & $-10 \%$ & $+10 \%$ & $+50 \%$ \\
\hline \multicolumn{5}{|c|}{ Perturbations in $\mathrm{CH}^{-1}$} \\
\hline$K_{x}$ & 0.0 & 0.0 & 0.0 & 0.0 \\
\hline$K_{y}$ & 0.0 & 0.0 & 0.0 & 0.0 \\
\hline Z & 0.0 & 0.0 & 0.0 & 0.0 \\
\hline \multicolumn{5}{|c|}{ Perturbations in $K_{x}$} \\
\hline $\mathrm{CH}^{-1}$ & 15.8 & 1.6 & -1.3 & -2.0 \\
\hline$K_{y}$ & 12.7 & 1.3 & -1.0 & -1.3 \\
\hline$Z$ & 0.0 & 0.0 & +0.6 & +0.6 \\
\hline \multicolumn{5}{|c|}{ Perturbations in $K_{y}$} \\
\hline $\mathrm{CH}^{-1}$ & 1342.9 & 53.6 & -27.9 & -68.3 \\
\hline$K_{x}$ & 202.1 & 29.1 & -15.3 & -40.0 \\
\hline$z$ & 65.2 & 7.0 & -6.3 & -22.2 \\
\hline \multicolumn{5}{|c|}{ Perturbations in $Z$} \\
\hline$C H^{-1}$ & -75.7 & -25.3 & 34.0 & 324.6 \\
\hline$K_{x}$ & -2.1 & -0.4 & 0.4 & 2.1 \\
\hline$K_{y}$ & 19.2 & 3.2 & -3.2 & -14.6 \\
\hline
\end{tabular}

that are variants of Eq. (3). Within the remaining 3 parameters, both $K_{x}$ and $Z$ are more sensitive to $K_{y}$ than they are to each other and $K_{Y}$ is about equally sensitive to $K_{x}$ and $Z$. The importance of $K_{y}$ follows from its magnitude; $\left(4 K_{y}\right)^{-1}$ is 1.5 times greater than $\left(4 K_{x}\right)^{-1}$ as is shown by the steeper slope of the transformed larval density on $y^{2} t^{-1}$ than $x^{2} t^{-1}$ for Cohort 6 in Fig. 5. The greater magnitude of $\left(4 K_{y}\right)^{-1}$ than $\left(4 K_{x}\right)^{-1}$ also explains why $K_{x}$ is much more sensitive to $K_{y}$ than $K_{y}$ is to $K_{x}$. The most important result of this sensitivity analysis is the observation that $Z$ decreases by only 22.2 and $0.6 \%$ for a $50 \%$ increase in $K_{y}$ and $K_{x}$ respectively. This indicates that both $K_{y}$ and $K_{x}$ would have to be increased by much more than $50 \%$ in order to reduce $Z$ by the $85 \%$ that is necessary to make it comparable to the $Z$ of Cohort 2. Since such a change in parameter values would greatly reduce the amount of explained variance, this analysis clearly shows that the large difference in $Z$ between Cohorts 2 and 6 is real and that it is not an artifact of population modelling.

The primary uncertainty associated with morphometric factors is the shrinkage and distortion of larvae by capture in towed nets [see Theilacker (1986) for a review of the morphometric method]. Corrections for shrinkage and distortion due to net capture were made in this study. Moreover, the accuracy of the morphometric condition factor is supported by Robinson \& Ware's (1988) report of similar timing and magnitude of starvation in Strait of Georgia herring larvae as is reported here for the Bamfield Inlet herring larvae. However, future studies of this kind should confirm these findings by employing at least one other index of starvation as well as morphometry. These would include indices based on histology of the fish (O'Connell 1980, Hewitt et al. 1985, Theilacker 1986) or on RNA/DNA ratios (Buckley \& Lough 1987, Robinson $\&$ Ware 1988)

The conclusion that predation, controlled or modified by offshore dispersal or population density, may be the dominant agent of mortality for some cohorts supports aspects of previous work conducted on Pacific herring larvae in British Columbia waters. Stevenson (1962) was the first to study the population dynamics of Pacific herring larvae in British Columbia. He concluded that the principal cause of death of larvae that hatched from spawn laid on the northwestern shore of Barkley Sound, (Fig. 1: Toquart Bay-Maggie River area and the islands opposite) was their passive transport by inshore water currents to the open sea. This was based on the observation that the greatest concentration of newlyhatched larvae was found in inshore waters, and as they were carried seaward the numbers decreased at an approximately constant rate. Stevenson (1962) did not examine the factors directly causing death in offshore waters, but he suggested that death may be caused by the high salinity of the open sea.

Although this report partially supports Stevenson's (1962) conclusion that offshore dispersal is linked with mortality in Barkley Sound herring larvae, it is possible that the factors that control the mortality of large cohorts, such as those that Stevenson (1962) studied on the northeastern coast of Barkley Sound, may be different from the factors that control mortality in smaller cohorts hatching in protected water.

Alderdice \& Hourston (1985) reviewed the field and experimental evidence on the effects of salinity and temperature on survival of Pacific herring eggs and yolk sac larvae and concluded that the upper boundary of larval tolerance to salinity is 27.5 to $31.7 \%$, which is near the lower end of the range of salinities commonly encountered in offshore waters of British Columbia. They also examined the distribution of herring larvae in the Strait of Georgia, where surface salinities are generally 27 to $28.6 \%$ and found that larvae from offshore areas of the Strait were actively feeding and growing. They concluded that the usual surface salinites and food supply in the open waters of the Strait were not a dominant influence on larval survival, and suggested that the disappearance of the larvae in the Strait of Georgia was largely the result of predation.

Predation is undoubtedly a major factor in the mortality of Pacific herring larvae; they are preyed upon by many species of fish (Brodeur et al. 1987), including adult and juvenile herring (Hourston \& Haegele 1980, Hourston et al. 1981), and pelagic invertebrates (Stevenson 1962, Westernhagen \& Rosenthal 1976. Arai \& Hay 1982). Predation has been implicated as the 
most important agent of mortality in wild larvae of the closely-related Atlantic herring (Moller 1984). Recently, Ware \& McFarlane (1986) have suggested that the survival of juvenile Pacific herring of the west coast of Vancouver Island is controlled by predation by adult Pacific hake Merluccius productus.

There are at least 2 reports suggesting that starvation may be an important cause of death in Pacific herring larvae. Westernhagen \& Rosenthal (1981) measured the condition factor ( $\mathrm{W} \mathrm{L}^{-3}$ ) of Pacific herring larvae in Departure Bay, British Columbia, in 1974 and 1976 and concluded that there were significant differences between years in the number of poorly-conditioned fish: at any given length the 1974 fish had better condition than the 1976 fish. However, Westernhagen \& Rosenthal (1981) also noted that the recruitment of adult herring to the Strait of Georgia stock resulting from the 1974 year-class was only half that of the 1976 year-class, a result opposite to that expected from Hjort's (1914) critical-period hypothesis if one assumes that the larval condition data in Departure Bay were representative of conditions throughout the Strait of Georgia. Robinson \& Ware (1988) confirmed the existence of starving Pacific herring larvae in the Strait of Georgia when they found that $28 \%$ of first feeding herring larvae captured in the Strait in 1986 had RNA/ DNA ratios below the level for zero protein growth, indicating that these larvae were experiencing protein loss due to starvation. However, Robinson \& Ware (1988) were not able to evaluate the role of starvation in the population dynamics of these fish because they did not estimate total mortality.

The results of this study are similar to the general conclusions reached by Leak \& Houde (1987) and Taggart \& Leggett (1987b) concerning the secondary role of starvation in the population dynamics of bay anchovy Anchoa mitchilli larvae in Biscayne Bay, Florida, and capelin Mallotus villosus larvae in southeast Newfoundland, respectively. On the other hand, other authors have demonstrated that starvation is the primary agent of mortality in first-feeding larvae of northern anchovy Engraulis mordax (O'Connell 1980), and jack mackerel Trachurus symmetricus (Hewitt et al. 1985, Theilacker 1986), off southern California. Some of the conclusions reached by all 5 authors are similar to those reached by this study: (1) $Z$ is sometimes highly variable between cohorts or between seasons; (2) starvation mortality occurs over a relatively short period of time soon after the exhaustion of yolk reserves; and (3) although starvation may be the major source of mortality in first-feeders, it may not be the dominant agent of mortality over the entire larval period, implying that variation in $Z$ may not always be due to variation in starvation mortality. It must be noted that the 2 studies that measured food density, Leak \&
Houde (1987) and Taggart \& Leggett (1987b), found little evidence to support a link between food density and survival of young fish larvae. All of these conclusions, except the first, do not support Hjort's (1914) original hypothesis of year-class formation by catastrophic starvation of first-feeding larvae. Instead, they support the concept that mortality in young fish larvae is a multifactor process with starvation being only one of several factors.

Acknowledgements. I thank the staff of the Bamfield Marine Station, S. Leader, A. Bergey, T Bedford and S. Tveit, for assistance in the collection of field samples, and N. Hoffmann and C. Moore of the U.B.C. Computing Center for assistance with nonlinear regression. K. Stubbs and C. Brodersen drafted the figures. This research was supported in part by 2 University of British Columbia Summer Research Scholarships and by a Graduate Research, Engineering and Technology Award from the British Columbia Science Council. The manuscript. benefited from reviews by several anonymous reviewers.

\section{LITERATURE CITED}

Able, K. W. (1978). Ichthyoplankton of the St. Lawrence estuary: composition, distribution, and abundance. J. Fish. Res. Bd Can. 35: 1518-1531

Alderdice, D. F., Hourston, A. S. (1985). Factors affecting development and survival of Pacific herring (Clupea harengus pallasi) eggs and larvae to the beginning of exogenous feeding. Can. J. Fish. Aquat. Sci. 42 (Suppl. 1): $56-68$

Arai, M. N., Hay, D. E. (1982). Predation by medusae on Pacific herring (Clupea harengus pallasi) larvae. Can. J. Fish. Aquat. Sci. 39: 1537-1540

Blaxter, J. H. S., Hunter, J. R. (1982). The biology of the clupeoid fishes. Adv. mar. Biol. 20: 1-223

Brodeur, R. D., Lorz, H. V., Pearcy, W. G. (1987). Food habits and dietary variability of pelagic nektoh off Oregon and Washington, 1979-1984. NOAA Tech. Rep. NMFS 57: 1-32

Buckley, L. J., Lough, R. G. (1987). Recent growth, biochemical composition, and prey field of larval haddock (Melanogrammus aeglefinus) and Atlantic cod (Gadus morhua) on Georges Bank. Can. J. Fish. Aquat. Sci. 44: $14-25$

Cleary, R. W., Adrian, D. D. (1973). New analytical solutions for dye diffusion equations. J. environ. Eng. Div. Am. Soc. Civ. Eng. 99 (EE3): 213-227

Das, N. (1968). Spawning, distribution, survival and growth of larval herring (Clupea harengus L.) in relation to hydrographic conditions in the Bay of Fundy. Fish. Res. Bd Can. Tech. Rep. 88: 1-129

Dennis, J. E., Jr., Gay, D. M., Welsch, R. E. (1981a). An adaptive least-squares algorithm. Assoc. Computing Mach. Trans. Math. Software 7: 348-368

Dennis, J. E., Jr., Gay, D. M., Welsch, R. E. (1981b). Algorithm 573 NL2SOL - an adaptive non-linear least-squares algorithm. Assoc. Computing Mach. Trans. Math. Software 7 : 369-383

Diachishin, A. N. (1963). Dye dispersion studies. J. sanit. Eng. Div., Am. Soc. Civ. Eng. 89 (SA 1): 29-49

Dragesund, O., Nakken, O. (1971). Mortality of herring during the early larval stage in 1967 . Rapp. R.-v. Réun. Cons. int. Explor. Mer 164: 142-146 
Dragesund, O., Nakken, O. (1973). Relationship of parent stock size and year class strength in Norwegian spring spawning herring. Rapp. P.-v. Réun. Cons. int. Explor. Mer 164: $15-29$

Fortier, L., Leggett, W. C. (1982). Fickian transport and the dispersal of fish larvae in estuaries. Can J. Fish. Aquat. Sci. 39: 1150-1163

Fortier, L., Leggett, W. C. (1983), Vertical migrations and transport of larval fish in a partially mixed estuary. Can. J. Fish. Aquat. Sci. 40: 1543-1555

Gay, D. M. (1983). Remark on algorithm 573. Assoc. Computing Mach. Trans. Math. Software 9: 139

Graham, J. J. (1972). Retention of larval herring within the Sheepscot estuary of Maine. Fish. Bull. U. S. 70: 299-305

Graham, J. J., Chenoweth, S. B. (1973). Distribution and abundance of larval herring (Clupea harengus) over egg beds on Georges Bank. Int. Comm. Northwest Atl. Fish. Res. Bull. 10: 141-149

Haegele, C. W., Fitzpatrick, L. C. (1983). The distribution of herring spawn and associated roe fisheries in British Columbia (1956 to 1980). Can. Tech. Rep. Fish. Aquat. Sci. 407 , p. $1-245$

Heath, M. R., MacLachlan, P. (1987). Dispersion and mortality of yolk-sac herring (Clupea harengus L.) larvae from a spawning ground to the west of the Outer Hebrides. J. Plankton Res. 9: 613-630

Henderson, P. A., Whitehorse, J. W., Cartwright, G. H. (1984) The growth and mortality of larval herring, Clupea harengus harengus L., in the River Blackwater Estuary, 1978-80. J. Fish Biol. 24: 613-622

Henri, M., Dodson, J. J., Powles, H. (1985). Spatial configurations of young herring (Clupea harengus harengus) larvae in the St. Lawrence estuary: importance of biological and physical factors. Can. J. Fish. Aquat. Sci. 42 (Suppl. 1): 91-104

Hewitt, R. P., Theilacker, G. H., Lo, N. C. H. (1985). Causes of mortality in young jack mackerel. Mar. Ecol. Prog. Ser. 26: $1-10$

Hjort, J. (1914). Fluctuations in the great fisheries of northern Europe. Rapp. P.-v. Réun. Cons. int. Explor. Mer 20: 1-228

Hourston, A. S., Haegele, C. W (1980). Herring on Canada's Pacific coast. Can. Spec. Publ. Fish. Aquat. Sci. 48, p. 1-23

Hourston, A. S., Hamer, J. M. (1979). Definitions and codings of localities, sections, management units and divisions for British Columbia herring data. Fish. Mar. Serv. MS Rep. 1533, p. 1-91

Hourston, A. S., Rosenthal, H., Kerr, S. (1981). Capacity of juvenile Pacific herring (Clupea harengus pallasi) to feed on larvae of their own species. Can. Tech. Rep. Fish. Aquat. Sci. 1044, p. 1-9

Hourston, A. S., Rosenthal, H., von Westernhagen, H. (1984). Viable hatch from eggs of Pacific herring (Clupea harengus pallasi) deposited at different intensities on a variety of substrates. Can. Tech. Rep. Fish. Aquat. Sci. No. 1274

Humphries, R. D., Hourston, A. D. (1978). British Columbia herring spawn deposition survey manual. Misc. Spec. Publ. Fish. Mar. Serv. Can. p. 1-40

Iizuka, A. (1966). Studies on the early life history of herring (Clupea pallasi C. et V.) in Akkeshi Bay and Lake Akkeshi, Hokkaido. Bull. Hokkaido Reg. Fish, Res. Lab. 31: 18-63

Iles, T D., Sinclair, M. (1982). Atlantic herring stock discreteness and abundance. Science 215: 627-633

Koslow, J. A., Brault, S., Dugas, J., Page, F. (1985). Anatomy of an apparent year-class failure: the early life history of the 1983 Browns Bank haddock Melanogrammus aeglefinus. Trans. Am. Fish. Soc. 114: 478-489
Kvålseth, T. O. (1985). Cautionary note about $\mathrm{R}^{2}$ Am. Stat. 39: 279-285

Leak, J. C., Houde, E. D. (1987). Cohort growth and survival of bay anchovy Anchoa mitchilli larvae in Biscayne Bay, Florida. Mar Ecol. Prog. Ser 37: 109-122

Lough, R. G., Bolz, G. R., Grosslein, M. D., Potter, D. C. (1981). Abundance and survival of sea herring (Clupea harengus L.) larvae in relation to environmental factors, spawning stock size and recruitment for the Georges Bank area, 1968-1977 Rapp. R.-v. Réun. Cons. int. Explor Mer 178: $220-222$

Marliave, J. B. (1980). Survival through metamorphosis of Pacific herring larvae prevented from schooling. Trans. Am. Fish. Soc. 109: 327-328

McGurk, M. D. (1984). Effects of delayed feeding and temperature on the age of irreversible starvation and on the rates of growth and mortality of larval Pacific herring. Mar. Biol. 84: $13-26$

McGurk, M. D. (1985a). Multivariate analysis of morphometry and dry weight of Pacific herring larvae. Mar. Biol. 86: $1-11$

McGurk, M. D. (1985b). The effects of net capture on the postpreservation morphometry, dry weight, and condition factor of Pacific herring larvae. Trans. Am. Fish. Soc. 114: $395-402$

McGurk, M. D. (1986). The role of starvation in the population dynamics of larval Pacific herring, Clupea harengus pallasi. Ph. D. thesis, University of British Columbia, Vancouver

McGurk, M. D. (1987a). Age and growth of Pacific herring larvae based on length-frequency analysis and otolith ring number Environ. Biol. Fish. 20: 33-47

McGurk, M. D. (1987b). Spatial patchiness of Pacific herring larvae. Environ. Biol. Fish. 20: 81-89

Möller, H. (1984). Reduction of a larval herring population by jellyfish predator. Science 224: 621-622

Moore, C. (1984). UBC Curve: curve fitting routines. Computing Centre, University of British Columbia, Vancouver

Moore, C. (1986). Double precision routines NL2SOL, NL2SNO. Computing Centre, University of British Columbia, Vancouver, B. C., Technical Note TN214 p. 1-7

Munk, P., Christensen, V., Paulsen, H. (1986). Studies of a larval herring (Clupea harengus L.) patch in the Buchan area. II. Growth, mortality and drift of larvae. Dana Rep 6: $11-24$

O'Connell, C. P. (1980). Percentage of starving northern anchovy, Engraulis mordax, larvae in the sea as estimated by histological methods. Fish. Bull. U. S. 78: 475-489

Okubo, A. (1971). Oceanic diffusion diagrams. Deep Sea Res. 18: $789-802$

Okubo, A. (1980). Diffusion and ecological problems: mathematical models. Lecture notes in biomathematics, Vol. 10. Springer-Verlag, Berlin

Powles, H., Auger, F., Fitzgerald, G. J. (1984). Nearshore ichthyoplankton of a north temperate estuary. Can. J. Fish. Aquat. Sci. 41: 1653-1663

Robinson, S. M. C., Ware, D. M. (1988). Ontogenetic development of growth rates in larval Pacific herring, Clupea harengus pallasi, measured with RNA-DNA ratios in the Strait of Georgia, Britisch Columbia, Can. J. Fish. Aquat. Sci. 45: 1422-1429

Rohlf, F. J., Sokal, R. R. (1969). Statistical tables. W. H. Freeman and Co., San Francisco

Rothschild, B. J. (1986). Dynamics of marine fish populations. Harvard University Press, Cambridge, Mass.

Sinclair, M., Iles, T. D. (1985). Atlantic herring (Clupea harengus harengus) distributions in the Gulf of Maine - 
Scotian Shelf area in relation to oceanographic features. Can. J. Fish. Aquat. Sci. 42: 880-887

Smith, P. E., Richardson, S. L. (1977). Standard techniques for pelagic fish egg and Iarvae surveys. FAO Fish. tech. Pap. 175: $1-100$

Stevenson, J. C. (1962). Distribution and survival of herring larvae (Clupea pallasi Valciennes) in British Columbia waters. J. Fish. Res. Bd Can. 735-810

Taggart, C. T., Leggett, W. C. (1987a). Short-term mortality in post-emergent larval capelin Mallotus villosus. I. Analysis of multiple in situ estimates. Mar. Ecol. Prog. Ser. 41: 205-207

Taggart, C. T., Leggett, W. C. (1987b). Short-term mortality in post-emergent larval capelin Mallotus villosus. II. Importance of food and predator density, and density-dependence. Mar. Ecol. Prog. Ser. 41: 219-229

Talbot, J. W. (1977). The dispersal of plaice eggs and larvae in the Southern Bight of the North Sea. J. Cons. int. Explor. Mer 37: 221-248

Talbot, J. W., Talbot, G. A. (1974). Diffusion in shallow seas and in English coastal and estuarine waters. Rapp. P.-v. Réun. int. Explor. Mer 167: 93-100

Theilacker, G. H. (1986). Starvation-induced mortality of young sea-caught jack mackerel, Trachurus symmetricus, determined with histological and morphological methods. Fish. Bull. U. S. 84: 1-17

Ware, D. M., McFarlane, G. A. (1986). Relative impact of Pacific hake, sablefish and Pacific cod on west coast of Vancouver Island herring stocks. Int. North Pac. Fish. Comm. Bull. 47: $67-77$

Westernhagen, H. von, Rosenthal H. (1976). Predator-prey relationship between Pacific herring, Clupea harengus pallasi, larvae and a predatory hyperiid amphipod, Hyperoche medusarum. Fish. Bull. U. S. 74: 669-674

Westernhagen, H. von, Rosenthal, H. (1981). On condition factor measurements in Pacific herring larvae. Helgoländer Meeresunters. 34: 257-262

Yin, M. C. Blaxter, J. H. S. (1987). Feeding ability and survival during starvation of marine fish larvae reared in the laboratory. J. exp. mar. Biol. Ecol. 105: 73-83

This article was processed by the late Dr Reuben Lasker; it was accepted for printing on September 23, 1988 